\title{
Többváltozós adatelemzéssel kombinált gyengített teljes reflexiós infravörös spektroszkópia az ásványos összetétel vizsgálatában
}

\author{
Udvardi Beatrix ${ }^{1,2 *}$, KovÁcs István János ${ }^{1,3}$, STERCEl Ferenc ${ }^{1}$, KónYA Péter ${ }^{1}$, FAnCsiK Tamás ${ }^{1}$, FALus György ${ }^{1}$
}

\author{
${ }^{1}$ Magyar Bányászati és Földtani Szolgálat, 1145 Budapest, Columbus u. 17-23. \\ ${ }^{2}$ Közlekedéstudományi Intézet Nonprofit Kft., 1119 Budapest, Than Károly u. 3-5. \\ ${ }^{3}$ Magyar Tudományos Akadémia, Csillagászati és Földtudományi Kutatóközpont, Geodéziai és Geofizikai Intézet, \\ Kövesligethy Radó Szeizmológiai Obszervatórium, 1118 Budapest, Meredek u. 18. \\ *e-mail: udvbeatrix@gmail.com
}

\section{Attenuated total reflection infrared spectroscopy combined with multivariate data analysis for studying modal composition}

Abstract

Quantitative interpretation of results obtained from Attenuated total reflection Fourier transform infrared (ATR FTIR) spectroscopy is difficult and for deeper insight it is necessary to employ various data-processing methods. These methods must be suitable for handling large multidimensional data sets and for exploring the complete spectral information simultaneously. The effective implementation of these multivariate data analysis methods, however, also requires the pre-treatment of data. The pre-processing of raw data helps in the elimination of noise and the enhancement of discriminating features. This study focuses on two commonly-used multivariate methods of analysis: principal component regression (PCR) and partial least squares regression (PLSR); these methods enable the extraction of mineralogical information from infrared spectra. The present study also discusses the various spectral preprocessing methods that are widely used in ATR FTIR spectroscopy.

A dataset of natural standards of common rock-forming minerals (calcite, dolomite, quartz, feldspar, muscovite, illite, smectite and kaolinite) and their synthetic mixtures was constructed to build PCR and PLSR models that link the mineralogy of the samples to their respective infrared spectral signatures. Infrared spectra of the samples were recorded from 400 to $4000 \mathrm{~cm}^{-1}$. As a reference, modal composition was also estimated from X-ray diffraction data. The resulting PCR and PLSR models were also tested on synthetic mixtures.

The overall conclusion for the constructed 24 models is that, with respect to prediction, PCR and PLSR provide similar results. Different types of spectral treatment have greater impact on the estimated modal composition than the studied multivariate methods. Furthermore, in the models the respective amounts of various minerals were estimated with different uncertainties; this was the result of the difference in the infrared light-absorbing capacity of minerals, overlapping bands and other physical effects.

Keywords: ATR FTIR, PCR, PLSR, chemometrics, mineral mixtures

Összefoglalás

A gyengített teljes reflexiós Fourier transzformációs infravörös spektroszkópia (ATR FTIR) mennyiségi eredményeinek értelmezése általában nehéz és az adatok mélyebb áttekintéséhez különböző adatfeldolgozási módszereket kell alkalmazni. Ezeknek a módszereknek alkalmasnak kell lenniük a nagyméretű többdimenziós adatkészletek kezelésére és ezzel együtt a teljes spektrális információ feltárására. E többváltozós adatelemzési módszerek hatékony végrehajtása azonban megköveteli az adatok előkezelését is. A nyers adatok előfeldolgozása segít a zaj kiküszöbölésében és a megkülönböztetố jellemzők kiemelésében. Ez a tanulmány olyan két általánosan használt többváltozós elemzésre — a fôkomponens regresszióra (PCR) és a parciális legkisebb négyzetek regresszióra (PLSR) — összpontosít, amelyekkel az infravörös spektrumokból származó ásványtani információk kinyerhetők, valamint az ATR FTIR spektroszkópiában széles körben alkalmazott spektrum-előfeldolgozási módszereket tárgyalja.

A PCR és PLSR modellek létrehozásához gyakori kôzetalkotó ásványok (kalcit, dolomit, kvarc, földpát, muszkovit, illit, szmektit és kaolinit) természetes sztenderdjeit és azokból készített szintetikus keverékek egy olyan adatkészletét állítottunk elő, amelyek összekapcsolják az ásványos összetételt az infravörös spektrumokkal. A minták spektrumait a $400-4000 \mathrm{~cm}^{-1}$ tartományban vettük fel. Továbbá referenciaként a röntgen-pordiffrakciós adatokból becsültük meg a minták ásványos összetételét. Az eredményül kapott PCR és PLSR modelleket szintetikus keverékekkel is teszteltük.

A felállított $24 \mathrm{db}$ modell arra utal, hogy a PCR és a PLSR eljárással hasonló eredményre jutunk. A különböző spektrum-feldolgozások nagyobb hatással vannak a becsült ásványos összetételre, mint a tanulmányozott többváltozós módszerek. Továbbá különböző ásványok mennyisége a modellekben különböző bizonytalansággal becsülhető, amelyet az ásványok eltérő infravörös fényelnyelő képessége, átfedő sávok és egyéb fizikai hatások okozhatnak. 


\section{Bevezetés}

A kőzetek és a bennük előforduló alkotók a különböző földtani folyamatok termékei, lenyomatai, ezért vizsgálatuk például az egykori klímára enged következtetni vagy alapját szolgáltathatják a felszíni és felszín alatti létesítmények biztonságos kialakításának. A kutatások során ezért gyakran merül fel igényként a kôzetek alkotóinak azonosítása és mennyiségi meghatározása, amelyre számos módszer ad lehetőséget. A legelterjedtebb és legtöbb információt ebből a szempontból a röntgen-pordiffrakció (XRD) nyújtja, de kiegészítóként, alternatívaként szerepet kap a termogravimetria (TA) és az infravörös spektroszkópia (FTIR) is.

Az elmúlt néhány évben, e módszerek földtudományi alkalmazása közül az egyik legintenzívebben az FTIR fejlôdik, amely elsősorban az olajipar esetében hozott eddig számottevó eredményeket (pl. RITZ et al. 2011, MüLLER et al. 2014). A vizsgálatok általában három FTIR módszer köré csoportosulnak - a kálium-bromid $(\mathrm{KBr})$ pasztillában végzett transzmissziós (TIR), diffúz reflektancia (DRIFT) és gyengített teljes reflexió (ATR FTIR). A DRIFT és az ATR FTIR közös előnye a TIR eljáráshoz képest, hogy minimális minta-előkészítést igényel és a KBr higroszkópos tulajdonságával, illetve a potencionálisan fellépő ioncserével sem kell számolnunk. Az ATR FTIR módszerrel a minták akár nedves állapotban vagy szuszpenzió formájában is vizsgálhatók, és a rövid mérési idôből adódóan nagyszámú elemzést tesz lehetôvé, valamint terepi alkalmazására is mód nyílik (Woods et al. 2014). Ebből adódóan a három FTIR módszer közül az utóbbi időben leginkább az ATR FTIR fejlesztésére helyeződött a hangsúly.

A pormintában lévô alkotók mennyiségének FTIR meghatározása - a folyadékokhoz hasonlóan — azon alapul, hogy az egyes elnyelések intenzitása lineárisan változik az anyag mennyiségével (1, Lambert-Beer törvény), és hogy a spektrumok az egyes komponensek spektrumainak egyszerú összegzésével (2) jönnek létre (DUYCKAERTS 1959, BERTAUX et al. 1998):

$$
\mathrm{i}=\sum_{\mathrm{j}=1}^{\mathrm{a}} 1 \varepsilon_{\mathrm{j}} c_{j}
$$

ahol (a) a komponensek száma a mintában, az intenzitás (i) az egyes komponensek koncentrációjából $\left(\mathrm{c}_{\mathrm{j}}\right.$ ) és fényelnyelési együtthatójából $\left(\varepsilon_{\mathrm{j}}\right)$ tevődik össze a mintán alkalmazott hullámhossz (1) mellett.

$$
I=\sum_{j=1}^{a} i_{j}
$$

ahol az egyes komponensek elnyelései $\left(i_{j}\right)$ megadják az összes intenzitást (I).

A mennyiségi elemzés kalibrációs spektrumok készítésével, illetve azokból a tiszta komponensek fényelnyelési együtthatójának (extinkciós koefficiensének) meghatározásával végezhetố el. A meghatározás pontossága esetenként elérheti az 1-5\%-ot, ezt azonban jelentősen befolyásolja a kristályosodottsági állapot, a rácsban lévő helyettesítések, a szemcseméret, illetve hogy a kalibrációhoz nem minden esetben állnak rendelkezésre tiszta fázisok és az egyes ásványok infravörös fénnyel való kölcsönhatásának erőssége is igen eltérô (MATTESON \& HERRON 1993). Ez utóbbira jó példa, hogy a kvarc infravörös intenzitása kisebb, mint ugyanakkora mennyiségú muszkovit ásványnak, hiszen a kvarc $\left(\mathrm{SiO}_{2}\right)$ egy mól Si-ot tartalmaz, míg a muszkovit $\left(\mathrm{KAl}_{2}\left(\mathrm{AlSi}_{3} \mathrm{O}_{10}\right)(\mathrm{F}, \mathrm{OH})_{2}\right)$ három mólt. Tehát attól, hogy egy porkeverék spektrumán ugyanakkora intenzitással szerepelnek a két ásványra jellemző abszorpciós sávok, az nem jelenti azt, hogy azonos koncentrációban is vannak jelen (JORDÁ et al. 2015). Ezért van szükség az ásványok fényelnyelési együtthatójának ismeretére a klasszikus mennyiségi spektroszkópiában.

A felsorolt nehézségek kiküszöbölésére egyes esetekben (pl. bauxit) a relatív intenzitások mérésével lehet a mennyiségi meghatározásokat elvégezni. Ebben az esetben az ásványok infravörös elnyelési sávjainak részarányát határozzuk meg a teljes abszorpcióhoz viszonyítva. Ezen kívül az ásványos összetétel becsléséhez felhasználhatunk sávpárarányokat és belsô referenciaanyagokat is (REIG et al. 2002, HENRY et al. 2017). A legtöbb geológiai minta ${ }^{1}$ infravörös spektruma azonban összetett, a megjelenô sávok szélesek, átlapolhatnak, és egy adott komponensnek jellemzően több hullámszámtartományban is van elnyelése. A megfeleló minta-elókészítés (pl. szárítás) ugyan javíthatja a spektrumok minőségét (Kovács et al. 2015), ám a kívánt információ megszerzéséhez a referenciaspektrumok mellett sok esetben elkerülhetetlen a többváltozós statisztikai módszerek — kemometria — alkalmazása. Elónye a többi kvantitatív módszerhez képest, hogy gyors és költségkíméló módon képes kinyerni a kőzetből származó információkat. Ezért a kemometriával kombinált ATR FTIR a geológiai rendszerek vizsgálatában egy viszonylag új és gyorsan fejlődó irányvonal (PALAYANGODA \& NGUYEN 2012, WASHBURN \& BiRDWELL 2013, MÜLLER et al. 2014).

Jelen tanulmányunk fố célja, hogy az infravörös spektroszkópiában két gyakran alkalmazott többváltozós statisztikai módszerrel - fókomponens-regresszióval (principal component regression, PCR) és a parciális legkisebb négyzetek regresszióval (partial least square regression, PLSR) kombinált ATR FTIR módszert ásványkeverékeken szemléltessük, kihangsúlyozva a spektrumfeldolgozás jelentôségét. Először röviden összefoglaljuk a PCR és PLSR módszerek legfontosabb aspektusait, amelyek földtudományi szakemberek számára érdekesek és fontosak lehetnek, majd egy ásványkeverék-sorozaton szemléltetjük a két modellalkotási eljárás előnyeit és korlátait.

\section{Spektrumok feldolgozása}

A többváltozós statisztikai elemzések előtt az infravörös spektrumokon célszerú különbözố transzformációs múveleteket végrehajtani annak érdekében, hogy minél jobban

${ }^{1}$ A geológiai és a statisztikai minta nem összekeverendő. Jelen esetben a minta úgy
értelmezendő, mint a matematikai minta egy eleme, amely a jellemezni kívánt geológiai közegnek egy része (Kovícs \& KovÁCSNÉ 2006). 
javítsuk az optikai jelpontosságot, csökkentsük a zajt és kiszúrjük a spektrumban jelentkezô finom változásokat, azaz megnöveljük a mintára vonatkozó információtartalmat.

A mérés során a kísérleti körülményekben bekövetkezett változásokból adódóan (pl. levegô nedvességtartalmának változása) és a minta detektálásakor történt esetleges szóródási veszteség miatt a spektrum alapvonala eltolódhat. Ekkor a nem nulla értéken futó spektrumalapvonalat egy görbeillesztési módszerrel korrigálhatjuk (GRIFFITHS \& DE HASETH 2007). A környező levegőből származó $\mathrm{CO}_{2}$ és $\mathrm{H}_{2} \mathrm{O}$ spektrumon való megjelenése szintén befolyásolhatja a kiértékelést, ha koncentrációjuk a háttérspektrum felvételének pillanatához képest a detektálás során változott. Ezeket a komponenseket a spektrum atmoszférikus kompenzációjával küszöbölhetjük ki (BRUKER OPTIK, 2011).

Az átfedő csúcsok elkülönítése, az alapvonal-eltolódás és a szemcseméretből fakadó spektrumbeli eltérések javítása érdekében általában az infravörös fényelnyelés hullámszám szerinti deriválását végezzük el (NAES et al. 2002). A deriválás előnye, hogy matematikailag lineáris múvelet, ezért ha a Lambert-Beer törvény érvényes az eredeti spektrumra, akkor teoretikusan bármely rendú derivált ugyanúgy felhasználható mennyiségi meghatározásra. A magasabb rendû deriváltakat azonban célszerû elkerülni, mert felerősíthetik a spektrális zajokat, ezért a kis mennyiségben jelenlévő komponensek felismerését megnehezítik. A spektrális zaj csökkentése érdekében simítást is végezhetünk a spektrumon. Fontos azonban szem előtt tartani, hogy a spektroszkópiai szoftverek a deriválási múveletet gyakran simítással kombinálva végzik el (általában Savitzky-Golay módszerrel - SAVITZKY \& GOLAY 1964), ezért tulajdonképpen az adott deriválási eljárás függvényében már egy simított spektrumot kapunk. Mivel a túlzott simítás a spektrális jelet torzíthatja, ezért önmagában nem célszerú alkalmazni a többváltozós elemzések bemenô adathalmazán (GEMPERLINE 2006).

Ezeken a múveleteken kívül a geológiai minták összetételének FTIR vizsgálatában a normalizálásnak is jelentôs szerepe lehet. A rutin infravörös spektroszkópiában a legnagyobb intenzitású sávhoz képest végezzük el a normalizálást, amely során a maximum intenzitást 1 értékűnek tekintjük — az intenzitás értékétől függetlenül — és ehhez képest számoljuk a többi sáv intenzitását (ADAMU 2010). Az ATR FTIR spektrumoknál a normalizálás különösen hangsúlyos, mert az infravörös fény az alkalmazott ATR egység tulajdonságainak és a minta törésmutatójának függvényében különbözô mélységben hatol a mintába (KovÁcs et al. 2015), azaz a kapott spektrum intenzitásai egy adott effektív vastagságra - az infravörös fény behatolási mélységére vonatkoznak (MiRABELLA 2002). Emellett, mivel a geológiai mintákat por állapotban vizsgáljuk, ezért az infravörös fény által megmintázott anyag mennyisége a szemcseméretnek és a porozitásnak is függvénye lesz (PLANINSEK et al. 2006, UdVARDI et al. 2016). Ez egyúttal azt is jelentheti, hogy mintánként eltérő mennyiségű anyagot mérhetünk, annak ellenére, hogy méréskor mindig azonos anyagmenynyiségek mérésére törekedünk. A becslési modellben ahhoz, hogy egységesen tudjuk kezelni az FTIR módszerrel felvett spektrumokat, az eltérő mintamennyiségből (DRIFT, ATR FTIR) vagy mintavastagságból (TIR) adódó különbségek korrigálására ezért valójában célszerú normalizálást használni, azonban nem mindegy, hogy milyen eljárás szerint, ezért ezt szemléletesen is bemutatjuk.

\section{Többváltozós adatelemzés}

Az infravörös spektrum intenzitásai és az ásványos összetétel közötti összefüggések feltárására többféle matematikai megoldás kínálkozik. Egyik lehetséges út a változókiválasztási módszerek alkalmazása. Ezeknek az eljárásoknak azért van jelentősége a spektrumok feldolgozásában, mert egy spektrum több száz - több ezer adatpontból (hullámszámok és a hozzájuk rendelhetô infravörös intenzitásértékekből) is állhat, ezért nehezen kezelhetô a sok változó. Ezek közül nem mindegyik hordoz lényegi információt, a manuális leválogatás azonban időigényes és nem feltétlenül objektív. Ezen túlmenően, mivel egy ásványhoz több abszorpciós sáv is rendelhetô, amelyek egymással korrelálnak, ezért a spektrum számos korrelálható változót is tartalmaz. A változó-kiválasztási módszerek lehetővé teszik, hogy mindezeket a számunkra felesleges jeleket az adathalmazból objektíven tudjuk leválogatni, megtartva a modell szempontjából ideális tagokat.

\section{Afókomponens-regresszió (PCR)}

A spektrumok feldolgozásában az egyik leggyakrabban alkalmazott módszer a fókomponens-regresszió (PCR), amelynek célja az, hogy a többváltozós adatsort az egyes változók (tulajdonságváltozók, pl. spektrum-intenzitások) mögötti, rejtett kapcsolatok feltárásával megpróbáljunk leírni egy kisebb dimenziós térben, minél kevesebb információ elvesztése árán. Ehhez először egy olyan mátrixba rendezzük az adatainkat, amely a $\mathrm{M}$ változókat (oszlopok, pl. spektrumok intenzitásai hullámszámonként) tartalmazza N db objektumonként (sorok, pl. minták):

$$
\mathrm{X}_{\mathrm{NM}}=\begin{array}{cccc}
\mathrm{x}_{11} & \mathrm{x}_{12} & \ldots & \mathrm{x}_{1 \mathrm{M}} \\
\mathrm{x}_{21} & \mathrm{x}_{22} & \ldots & \mathrm{x}_{2 \mathrm{M}} \\
\vdots & \vdots & & \vdots \\
\mathrm{x}_{\mathrm{N} 1} & \mathrm{x}_{\mathrm{N} 2} & \ldots & \mathrm{x}_{\mathrm{NM}}
\end{array}
$$

Az elemzés során az egymással kölcsönösen összefüggő változók közötti kapcsolatokat vizsgáljuk úgy, hogy az eredeti változókat egy ortogonális (meróleges) térbe helyezzük, amelynek eredményeként az eredeti paraméterszámnak megfelelő „mesterséges” korrelálatlan változókat, ún. főkomponenseket hozunk létre (GELADI \& KowALSKY 1986). Ehhez az eredeti adatmátrixot két mátrix — a főkomponens-együttható mátrix (P, vetítési mátrix) és a fókomponens mátrix $(\mathrm{T})$ - szorzatára bontjuk fel:

$$
\mathrm{X}=T P^{\mathrm{T}}+E
$$

amelyből a főkomponensek az eredeti változók lineáris 
kombinációjaként állnak elő (MARTENS \& NAES 1989), példaként az elsố fôkomponens:

$$
\begin{aligned}
& \mathrm{t}_{11}=\mathrm{x}_{11} \mathrm{p}_{11}+\mathrm{x}_{12} \mathrm{p}_{21}+\cdots+\mathrm{x}_{1 \mathrm{M}} \mathrm{p}_{M 1} \\
& \mathrm{t}_{21}=\mathrm{x}_{21} \mathrm{p}_{11}+\mathrm{x}_{22} \mathrm{p}_{21}+\cdots+\mathrm{x}_{2 \mathrm{M}} \mathrm{p}_{M 1} \\
& \vdots \\
& \mathrm{t}_{\mathrm{N} 1}=\mathrm{x}_{N 1} \mathrm{p}_{11}+\mathrm{x}_{\mathrm{N} 2} p_{21}+\cdots+\mathrm{x}_{\mathrm{MM}} \mathrm{p}_{\mathrm{M} 1}
\end{aligned}
$$

A fókomponens mátrix oszlopai a főkomponens-vektorok (scores), míg a fókomponens-együttható mátrix sorai pedig a fốkomponens-együttható vektorok (loadings) lesznek. A két mátrix mellett egy hiba mátrix (E) is felírható. Ennek értéke nulla, ha az összes főkomponens és fókomponens-együttható vektort kiszámoljuk.

Ezzel az átalakítással tulajdonképpen az eredeti változók által kifeszített teret a fókomponensek segítségével alacsonyabb dimenziójú térbe vetítjük egy vetítési mátrix segítségével, és így az objektumok koordinátáit a fő́komponensek hipersíkjában kapjuk meg (1. ábra). A fókomponenseket grafikusan tehát úgy tekinthetjük, mint egy új derékszögû́ koordinátarendszer tengelyeit, értékeit pedig mint az eredeti változók vetítéseit ezekre a tengelyekre.

A főkomponens-együtthatókhoz tartozik egy magyarázott variancia érték (sajátérték) is, ami azt mutatja meg, hogy az adott főkomponens hány százalékát magyarázza az eredeti változók együttes varianciájának (tehát a példaként

(a)

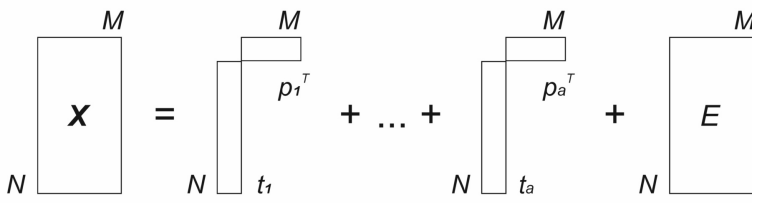

(b)

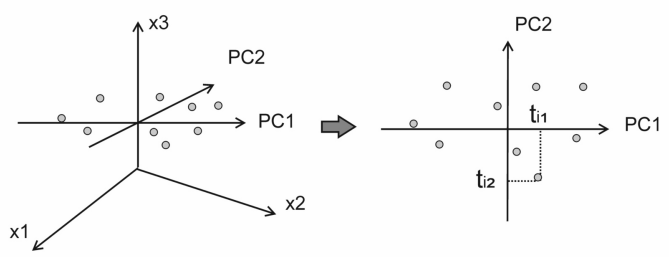

1. ábra. Az eredeti adatmátrix $(X)$ felbontásának szemléltetése (a). Mindegyik mártix $\mathrm{N}$ sorból és M oszlopból áll. E a hibamátrix, $\mathrm{p}(\mathrm{i}=1, \ldots \mathrm{a})$ a fökomponensegyüttható, míg $\mathrm{t}(\mathrm{i}=1, \ldots$ a) a fökomponens. A fökomponens-regresszió sematikus szemléltetése (b). A változókat (x1, x2, x3) új koordináta rendszerbe transzformáljuk, ahol az objektumok egy-egy pontnak felelnek meg a térben, a koordinátatengelyek pedig a változóknak. Az adatokra egy olyan vonalat illesztünk, amely leképezi az adatok maximális varianciáját. Ez lesz az első fökomponens (PC1). Erre az egyenesre a fökomponens-vektorok ( $\left.\mathrm{t}_{\mathrm{i}}\right)$ vetítik le az objektumokat, így az eredeti objektum és vetitett képe közötti távolságot reprezentálják. A második főkomponens (PC2) az első fökomponens által le nem írt maradék varianciára illeszkedik és merőleges PC1-re

Figure 1. Decomposition of the original data matrix $(X)$ is shown (a). Each matrix has $N$ rows and $M$ columns. $E$ is referred to as the error or residual matrix; $p(i=1$, $\ldots$ a) as load vector; and $t(i=1, \ldots$ a) as score vector. Schematic illustration of the principal component regression $(b)$. The variables $(x 1, x 2, x 3)$ are transformed to a new coordinate system with one axis for each variables thereby converting the data set to points in a multidimensional space. A line is constructed through the data swarm which best describes the difference in the data set (the variance). The line is termed principal component one, PCl. The score value $t_{i}$, is obtained by the projection of the point $(i)$ onto the PCl line, and is the distance from this projection point to the origin. The PC2 is obtained by plotting a line through the data which next best describes the variance in the data; this must be orthogonal to the first principal component szereplő X mátrix összes elemére számított szórásnégyzetnek). Ez alapján határozzuk meg a főkomponensek sorrendiségét is. Az első fókomponens a variancia lehetô legnagyobb részét magyarázza, a második a második legtöbb varianciát magyarázza és így tovább. Emellett, mivel a mesterséges változók ortogonálisak, a fókomponensek egymásra merólegesek és korrelálatlanok.

A fớkomponensek kiválasztását különböző módszerekkel optimalizálhatjuk. Általános megoldás, hogy csak azokat tartjuk meg, amelyek egy eredeti változónyi információnál többet tartalmaznak. Ezek lesznek az 1-nél nagyobb sajátértékú főkomponensek. Vagy az eredeti változók információtartalmának csak egy adott százaléknyi értékét tartjuk meg. Ezek a változókiválasztási módszerek azonban alapvetôen szubjektív döntésen alapulnak, ezért számos automatizált megoldás is létezik (MARTENS \& NAES 1989).

A PCR-t háttértényezők keresésére használhatjuk, ha az adott főkomponenshez tulajdonságot tudunk társítani. Példaként, mivel az infravörös spektrumokon többnyire sok ismétlődő, korrelált komponens jelenik meg (pl. vízgőz, széndioxid abszorpciós sávjai, felhangok, egy komponenshez rendelhetô több elnyelési sáv), ezért általában már az elsô néhány fókomponens leírhatja a spektrumokból felállított adathalmazunk varianciájának nagy részét. A többi főkomponenstől - amelyek fóként zajt és egyéb zavaró effektusokat tartalmaznak — így ezek a fókomponensek elválaszthatók, és később bemeneti adatként szolgálhatnak a kvantitatív elemzésekhez. A főkomponensek általában egyszerre több ásványra, ásványokra jellemző tulajdonságot tartalmazhatnak, amelyeket különböző súllyal emelnek ki, de ha egyértelmú információt hordoznak, akár el is nevezhetjük a főkomponenseket (pl. kalcit spektrális tulajdonságait hordozó fökomponens).

A fókomponensek elemzése után a kiválasztott új változókat tekintjük független változóknak, és többváltozós lineáris regressziót végzünk köztük és a függő változók (pl. ásványos összetétel) közt:

$$
\begin{gathered}
\mathrm{R}^{2}=1-\sum_{\mathrm{i}=1}^{\mathrm{N}} \frac{\left(\mathrm{y}_{\mathrm{i}}^{\text {(becsült })}-\mathrm{y}_{\mathrm{i}}^{\text {(mért) }}\right)^{2}}{\sum_{\mathrm{i}=1}^{\mathrm{N}}\left(\mathrm{y}_{\mathrm{i}}^{(\text {mért })}-\overline{\mathrm{y}}^{\text {(mért })}\right)^{2}}=\frac{\mathrm{SSR}}{\mathrm{SST}} \\
\overline{\mathrm{y}}^{\text {(mért })}=\sum_{i=1}^{\mathrm{N}} \frac{\mathrm{y}_{\mathrm{i}}^{(\text {mért })}}{\mathrm{N}}
\end{gathered}
$$

A regresszió eredményeként a determinációs együtthatókkal ( $\mathrm{R}^{2}$, a korrelációs együttható négyzete) kifejezhetjük, hogy a regresszió hány \%-ban magyarázza a teljes szórásnégyzetet. A determinációs együttható a regressziós becslések átlagtól vett eltérésnégyzet-összegének (SSR) és a függő változó átlagtól vett eltérésnégyzet-összegének (SST) hányadosa.

A fent ismertetett transzformációt végrehajthatjuk kovariancia mátrixon vagy korrelációs mátrixon is. Amennyiben a kovariancia mátrixot elemezzük, az eredmény függ a változók skálájától, mivel eltéró mértékegységek esetén a változók nem arányosan fejtik ki hatásukat a főkomponensekre. Ennek 
elkerülése érdekében nem a kovariancia mátrixot, hanem a korrelációs mátrixot elemezzük. A korrelációs mátrix egy szimmetrikus mátrix, aminek az átlójában 1 van:

$$
\begin{array}{cccc}
1 & \operatorname{cor}\left(\mathrm{X}_{1}, \mathrm{X}_{2}\right) & \ldots & \operatorname{cor}\left(\mathrm{X}_{1}, \mathrm{X}_{\mathrm{M}}\right) \\
\operatorname{cor}\left(\mathrm{X}_{2}, \mathrm{X}_{1}\right) & 1 & \ldots & \operatorname{cor}\left(\mathrm{X}_{2}, \mathrm{X}_{\mathrm{M}}\right) \\
& & \vdots & \\
\operatorname{cor}\left(\mathrm{X}_{\mathrm{M}}, \mathrm{X}_{1}\right) & \operatorname{cor}\left(\mathrm{X}_{\mathrm{M}}, \mathrm{X}_{2}\right) & \ldots & 1
\end{array}
$$

A páronkénti korrelációkat az alábbi módon számítjuk:

$$
\operatorname{cor}\left(X_{i}, X_{j}\right)=\frac{\operatorname{cov}\left(X_{i}, X_{j}\right)}{\sigma_{i} \sigma_{j}}=\frac{E\left[\left(X_{i}-\mu_{i}\right)\left(X_{j}-\mu_{j}\right)\right]}{\sigma_{i} \sigma_{j}}
$$

ahol cor a korreláció, cov a kovariancia, $\sigma_{\mathrm{i}}$ és $\sigma_{\mathrm{j}} \mathrm{az} \mathrm{X}_{\mathrm{i}}$ és $\mathrm{X}_{\mathrm{j}}$ tetszôleges változók sztenderd szórásai, míg $\mu_{\mathrm{i}}$ és $\mu_{\mathrm{j}} \mathrm{a}$ változók valószínúségi eloszlásának az átlaga.

\section{A parciális legkisebb négyzetek regresszió (PLSR)}

A főkomponens-regresszióhoz hasonlóan a parciális legkisebb négyzetek regresszió (PLSR) is egy olyan adattömörítő eljárás, amely során az adathalmazból virtuális tulajdonságokat hozunk létre. A PLS komponensek előállításához ez esetben azonban már nem csak a rendelkezésre álló adatokat, pl. spektrális adathalmazt használjuk — úgy mint a fookomponensek megalkotásánál —, hanem azokat a referenciaadatokat, függô változókat is hozzárendeljük a meglévő adatokhoz, amelyeket például klaszszikus meghatározással (pl. XRD-vel meghatározott ásványos összetétele a mintáknak) kaptunk (DE JONG 1993, Wold et al. 2001). A kiindulási változók helyett ún. látens vagy rejtett változókat használunk. A számítás során arra törekszünk, hogy a két adatmátrix rejtett változói között a korreláció maximális legyen, feltételezve, hogy közöttük lineáris kapcsolat áll fenn. Ehhez először a két adatmátrixot a PCR-hez hasonlóan külön-külön két mátrix szorzatára bontjuk fel:

$$
\begin{aligned}
& \mathrm{X}_{\mathrm{N}, \mathrm{M}}=\mathrm{T}_{\mathrm{N}, \mathrm{L}} \mathrm{P}_{\mathrm{L}, \mathrm{M}}{ }^{T}+E \\
& \mathrm{Y}_{\mathrm{N}, \mathrm{K}}=\mathrm{U}_{\mathrm{N}, \mathrm{L}} \mathrm{V}_{\mathrm{L}, \mathrm{K}}{ }^{T}+F
\end{aligned}
$$

ahol $\mathrm{K}$ a függő változók száma, T és $\mathrm{U}$ a változók rejtett változóinak mátrixa (scores), $\mathrm{P}$ és $\mathrm{V}$ pedig a hozzájuk tartozó együttható mátrixok (loadings). Majd megkeressük a két adatmátrix azon rejtett változóit, amelyek között a korreláció a lehetố legnagyobb:

$$
\mathrm{u}_{1 \mathrm{~N}, 1}=\mathrm{q}_{11} \mathrm{t}_{1 \mathrm{~N}, 1}
$$

ahol $\mathrm{u}_{1}$ és $\mathrm{t}_{1}$ a változók l-edik rejtett változója, $\mathrm{q}_{11}$ pedig a becsülendő l-edik regressziós együttható.

A PLSR iterációs eljárásban hajtja végre ezt az összevetést a két adathalmazon, amely azt jelenti, hogy az adathalmazból lépésenként kivonódik a spektrum- és a referenciaadatok egy része, miközben újabb PLS komponenseket képezünk mindaddig, amíg a teljes adathalmaz változékonyságát le nem fedi a modell. Ezen kívül a felbontott mátrixokhoz a hiba mátrixok is felírhatók, ha a PLS komponenseket iterációs eljárásban kivonjuk az eredeti adatmátrixból. Ha az összes PLS komponenst felírjuk, akkor a hibamátrixok értéke nulla lesz.

A PLSR módszerhez általában kevesebb számú változó szükséges, mint a PCR módszerhez, hogy ugyanakkora becslési hibát érjünk el, mivel a függő változóban meglévő információt is felhasználjuk a becslés során, de ez nem jelenti feltétlenül azt, hogy a PLSR-rel jobb eredményre jutnánk (WENTZELL \& MonTONO 2003). A komponensek kiválasztása a PCR módszernél ismertetett módokon történhet manuális leválogatással és szoftveresen vezérelve. Jelen esetben a keresztellenőrzés egy speciális esetét vettük alapul, ezért erre a megoldásra térünk ki részletesebben.

A PLS komponensek elemzése után a kiválasztott új változók és a becsülni kívánt változók között a többváltozós lineáris regressziót a PCR módszernél ismertetett módon végezzük el.

\section{Modellek jóságmutatói és a komponensek kiválasztása}

A PCR során a főkomponensek, a PLSR során pedig a PLS komponensek kiválasztását, illetve a modellek jóságát, becslési pontosságát a becsült és az ismert ásványos összetételi adatokra számolt közepes négyzetes eltéréssel (RMSE) ellenőrizhetjük:

$$
\text { RMSE }=\sqrt{\frac{\sum_{\mathrm{i}=1}^{\mathrm{N}}\left(\mathrm{y}_{\mathrm{i}}^{\text {(becsült })}-\mathrm{y}_{\mathrm{i}}^{\text {(mért })}\right)^{2}}{N}}
$$

ahol $\mathrm{N}$ a minták száma, $\mathrm{y}_{\mathrm{i}}$ a modell által becsült és a mért koncentrációérték.

Az RMSE rámutat arra, hogy a modellben megfelelően választottuk-e meg a főkomponensek, illetve a PLS komponensek számát. Ha túl sok főkomponenssel dolgozunk, a modell hibája ugyan csökken, de elveszíti robusztusságát, így külső validációt (azaz a természetes geológiai minták összetételének becslését) csak nagy hibával tudunk majd végezni, azaz túlillesztett modellhez jutunk. A túl kevés fơkomponens bevonása viszont alulillesztett modellt eredményez, a becslés hibája bár kicsi lesz, a modell hibája nagy. A megfelelő számú főkomponens kiválasztásánál ezért nemcsak a becsült és az ismert adatokra számolt közepes négyzetes eltérést vesszük figyelembe, hanem a modelladatokon a keresztellenőrzés során becsült átlagos négyzetes eltérést is. Az RMSE számolására több lehetôség van: elvégezhetjük a modell építése elején a keresztellenőrzéssel, ha a modellból kiveszünk spektrumokat, és azok összetételét megbecsüljük a modell maradék tagjaival, vagy tesztmintákkal való összevetés révén. A becsült és a mért adatok összevetéséből származó determinációs együtthatók révén pedig jellemezhetjük, hogy a modell milyen mértékben képes magyarázni a mért értékeket. 


\section{Minta-elókészítés}

A vizsgálatokhoz az üledékes kőzetekben gyakori ásványok természetes referenciaanyagait — kalcit, dolomit, kvarc, földpát, muszkovit, illit (IMt-1), szmektit (SWy-2), kaolinit (KGa-1) — és azok keverékéból alkotott 41 db pormintát használtuk fel. A referenciákról további részleteket a következô munkák nyújtanak: CHIPERA \& BISH (2001), UDVARDI et al. (2016).

A referenciákat porcelánmozsárban porítottuk, majd 63 $\mu \mathrm{m}$ lyukátmérőjủ szitán átszitáltuk és XRD-vel ellenőriztük az összetételüket (I. táblázat). Az ásványkeverékek összeállításánál arra törekedtünk, hogy az üledékes rendszerekre általában jellemző ásványos összetételt minél jobban lefed- jük. 4-8 komponensú ásványkeverékeket hoztunk létre, amelyek előállításához a porított sztenderdeket analitikai mérlegen $( \pm 0,00001 \mathrm{~g})$ bemértük, majd homogenizáltuk. A tömegbemérés pontosságát visszamérésekkel ellenőriztük és összetételük meghatározásához független módszerként szintén XRD-t alkalmaztunk. A mérlegen bemért mennyiségeket az 1.digitális mellékletben közöljük.

\section{Módszerek}

\section{Röntgen-pordiffrakció}

A röntgenfelvételek $40 \mathrm{kV}$ gyorsító feszültség és $30 \mathrm{~mA}$ áramerősség mellett egy Cu-katódcsővel és grafit mono-

I. táblázat. A természetes sztenderdek és szintetikus keverékek XRD-vel meghatározott összetétele

Table I. The modal composition observed by XRD in natural standards and synthetic mixtures

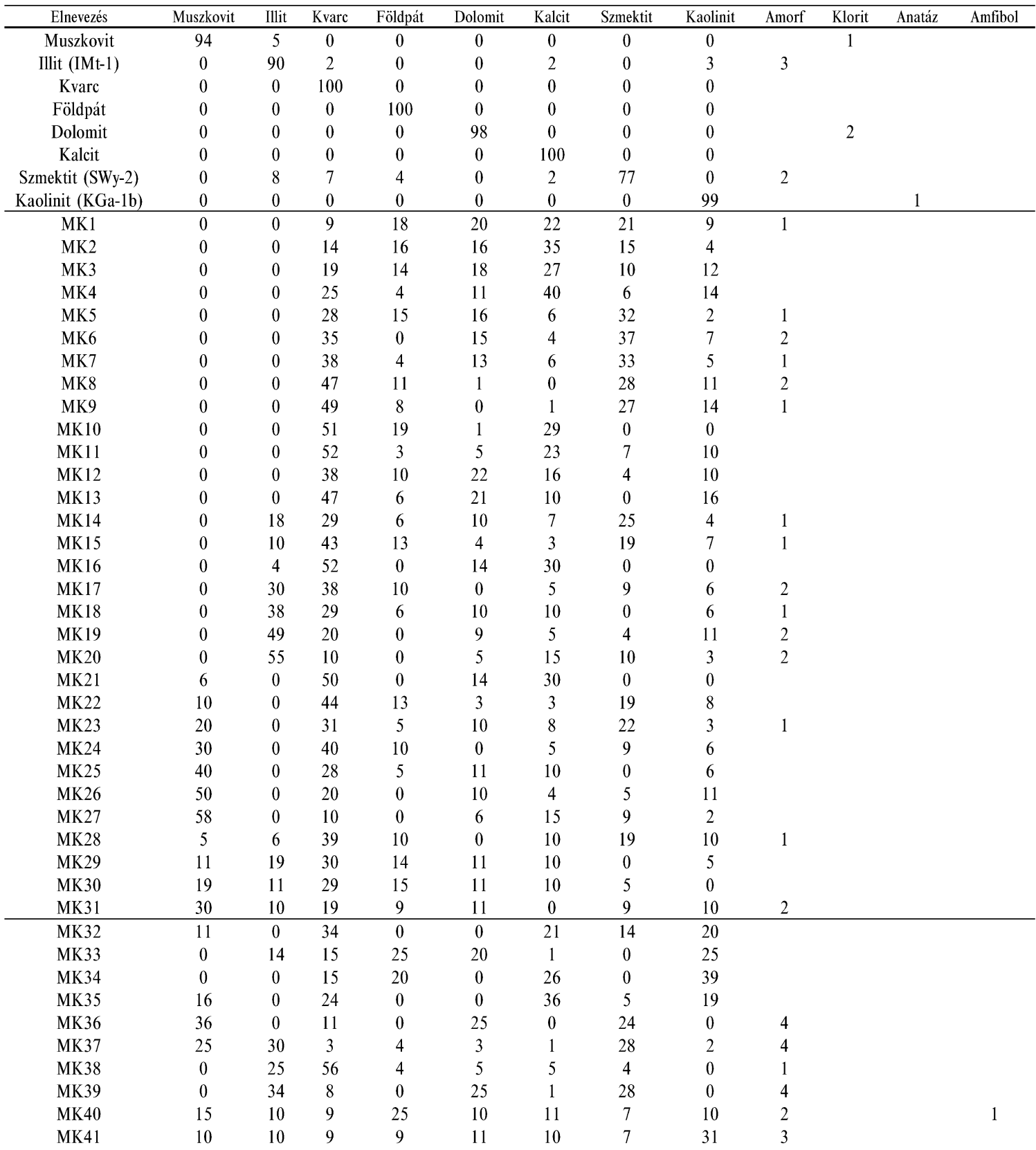


kromátorral felszerelt Philips PW 1730 diffraktométerrel készültek. A mérési tartomány $2-66^{\circ} 2 \Theta$ volt $2^{\circ} 2 \Theta$ /perc goniométersebesség mellett. Az ásványos összetétel számítása az XDB Power Diffraction Phase Analytical System 2.7 szoftverben (SAJó 1994) az ásványok specifikus reflexióinak relatív intenzitásarányai alapján az ásványokra vonatkozó irodalmi, illetve tapasztalati korundfaktorok alkalmazásával történt (KLUG \& ALEXANDER 1954).

\section{Gyengített teljes reflexiós infravörös spektroszkópia}

Az infravörös spektrumok felvételét egy Bruker Platinum egyszeres reflexiójú ATR feltéttel ellátott Bruker Vertex 70 Fourier transzformációs infravörös (FTIR) spektrométerrel végeztük, amelyhez Globar sugárforrás és MCT (higany-kadmium-tellurid) detektor csatlakozik (KovÁcs et al. 2015). Az ATR feltét optikai eleme gyémántkristály, amelyben egyszeres visszaverôdést szenved az infravörös fény $45^{\circ}$-os beesési szög mellett. A háttér és a minta spektrumait 400-4000 $\mathrm{cm}^{-1}$ közötti hullámszámtartományban, 4 $\mathrm{cm}^{-1}$ felbontással és 64-szeres futtatással vettük fel. A mintákat a felületi nedvesség minimalizálása érdekében a mérést megelőzóen $80^{\circ} \mathrm{C}$-on kiszárítottuk. A méréseket minden mintán legalább 5 mintaadagból ismételtük meg.

A spektrumok feldolgozását az OPUS 6.5 szoftverben végeztük el. A spektrumokat háttérkorrigáltuk (,rubberband" korrekció, 2-szeres iteráció), átlagoltuk, majd kiimportáltuk a további múveletekhez. Ha a $3000-3700 \mathrm{~cm}^{-1}$ tartományban észleltük a spektrumon a levegőból származó vízgốz abszorpciós sávjait, atmoszférikus kompenzációt is végeztünk még az átlagolást megelőzően. A rutin értékelésen kívül háttérkorrigálatlan, simítás nélküli derivált, valamint maximum abszorbancia és összabszorbancia szerinti normalizált spektrumadatokkal is dolgoztunk. A maximum abszorbancia során a legnagyobb intenzitású sáv magasságát 1 értékúnek tekintjük és a többi sávintenzitást ehhez képest arányosítottuk. Az összabszorbancia szerinti normalizálás során a spektrum összintenzitás értékével elosztottuk az eredeti spektrum minden egyes intenzitásértékét és megszoroztuk százzal.

\section{Modellalkotás és tesztelés}

A modellalkotáshoz a természetes sztenderdek és az ásványkeverékek (I. táblázat, 31 db, MK1-től MK31-ig) spektrumait és XRD adatait használtuk fel. További $10 \mathrm{db}$ minta adatán (MK32-tôl MK41-ig) pedig a modellek tesztelését végeztük el. A PCR és PLSR modelleket a GNU Octave 4.0.0 programban hoztuk létre és futtattuk le a statistics csomag felhasználásával (EATON et al. 2015). A különbözó spektrumfeldolgozási módszerek összehasonlítása érdekében korrelációs mátrixokkal dolgoztunk. A mért adatokból többféle modellt felállítottunk, hogy szemléltessük a különböző spektrumfeldolgozási lépések és azok kombinációinak jelentőségét (II. táblázat). Vizsgáltuk a
II. táblázat. A spektrumokon végrehajtott feldolgozási műveletek: A: nincs feldolgozási művelet, b: háttér korrekció, N: az összabszorbancia, NM: a maximum abszorbancia szerinti normalizálás, 1d: első derivált, $2 \mathrm{~d}$ : második derivált

Table II. Pre-processing methods are performed on spectral data: A: no pre-processing, $b$ : background correction, $N$ : normalization by total absorbance and NM: by maximum absorbance, 1d: first derivative, $2 d$ : second derivative

\begin{tabular}{cccccc}
\hline Modellek & \multicolumn{4}{c}{ Spektrumkezelési müveletek } \\
elnevezése & $\mathrm{b}$ & $\mathrm{N}$ & $\mathrm{NM}$ & $1 \mathrm{~d}$ & $2 \mathrm{~d}$ \\
\hline $\mathrm{A}$ & & & & & \\
$\mathrm{N}$ & & $\checkmark$ & & \\
1d & & & & & \\
2d & & & & & \\
N1d & & $\checkmark$ & & & $\checkmark$ \\
N2d & & $\checkmark$ & & & \\
\hline b-A & $\checkmark$ & & & & \\
b-N & $\checkmark$ & $\checkmark$ & & & \\
b-1d & $\checkmark$ & & & $\checkmark$ & \\
b-2d & $\checkmark$ & & & & \\
b-N1d & $\checkmark$ & $\checkmark$ & & $\checkmark$ & \\
b-N2d & $\checkmark$ & $\checkmark$ & & \\
\hline c-NM & $\checkmark$ & & $\checkmark$ & \\
c-NM1d & $\checkmark$ & & $\checkmark$ & $\checkmark$ \\
\hline & & & & \\
\hline
\end{tabular}

háttérkorrekció, normalizáció és a deriválás, illetve annak fokának hatását a modellek becslési képességeire. Feldolgozási lépésenként a modellek külön elnevezést kaptak. Továbbá azokból a spektrumokból is létrehoztunk modelleket, amelyeken nem hajtottunk végre spektrumkezelési múveleteket (1. II. táblázat, „A” jelöléssel). Összességében a PCR és a PLSR modellekben is $12 \mathrm{db}$ feldolgozási megoldást alkalmaztunk és hasonlítottunk össze. Továbbá a maximum intenzitás szerinti normalizálás szemléltetésére két-két PCR és PLSR modellt is létrehoztunk.

A modellek főkomponenseinek, illetve PLS komponenseinek kiválasztásához és ellenőrzéséhez részhalmazokra osztással végzett keresztellenôrzést használtunk, mert így az összes modelltagot be tudtuk vonni a vizsgálatba. A $39 \mathrm{db}$ mintához tartozó spektrális adatokból véletlenszerúen mindig kiválasztottunk $3 \mathrm{db}$-ot, és a maradék $36 \mathrm{db}$ minta segítségével megbecsültü̈k az ásványos összetételüket. A megszokott keresztellenőrzésekkel szemben az összes lehetséges részhalmaz kombinációra elvégeztük a keresztellenőrzést $(8125$ $\mathrm{db}$, ha a $3 \mathrm{db}$ véletlenszerúen kiválasztott részhalmaztagból csak 1 sztenderd megengedett), így pontosabb képet kaptunk arról, hogy a modell mennyire stabil és hogy hány fốkomponens, illetve PLS komponens optimális az ásványos összetétel becsléséhez. Ilyen mennyiségú adatnál a random kombinációk összes lehetséges változata lefuttatható, azonban minél több elemú tagból áll a modell és a random részcsoportok, annál több idốt vesz igénybe a számolás a lehetséges kombinációk számának növekedése miatt.

A modellek pontosságát a mintákra becsült ásványos összetétel és az XRD-vel meghatározott ásványos összetétel 
összehasonlításával értékeltük. Ehhez a mintákban lévő 8 db ásványfázis (muszkovit, illit, kvarc, földpát, kalcit, dolomit, szmektit, kaolinit) XRD-vel meghatározott mennyiségét használtuk. A kis mennyiségben előforduló alkotókat (amorf, amfibol, anatáz, klorit), amelyekból nem rendelkeztünk természetes sztenderddel, nem vettük figyelembe a modellekben.

\section{Eredmények és diszkusszió}

\section{A modellek keresztellenórzésének eredménye, modell optimalizáció}

A $8 \mathrm{db}$ ásványsztenderden és azok 31 db keverékén végzett teljes keresztellenőrzés eredménye alapján látható, hogy a modellek (1. II. táblázatban a modellek elnevezését) legkisebb átlagos négyzetes eltérése (L-RMSE) 5,7 és 10,8\% között változik (III. táblázat). Eltekintve a spektrumfeldolgozási múveletektől, a PCR és a PLSR modell között minimális eltérések vannak. A két modellalkotási eljárás egyedül a deriválási múveleteknél különül el kissé, de a LRMSE értéke ez esetben is csak néhány tized százalékban különbözik. A spektrumok feldolgozásának azonban annál jelentősebb hatása van a modellek jóságára. Megfigyelhető, hogy a legjobb közelítést az összabszorbancia szerinti normalizált spektrumokkal alkotott modellek adják $(5,7-$ $5,9 \%$ ), függetlenül attól, hogy végeztünk-e megelőzően háttérkorrekciót a felvételeken vagy nem. Az RMSE értéke alapján az összabszorbancia szerinti normalizálás mellett, ha egyéb múveletet is alkalmazunk, érdemben már nem fog javulni a modell. Kiemelve például a deriválást, tehát látható, hogy ettôl a múvelettől nem lesz jobb az RMSE értéke, sôt, a második derivált spektrumok adják a legnagyobb becslési bizonytalanságot a többi előkezeléssel összevetve. Ezen kívül megfigyelhető, hogy a két normalizálási eljárást

III. táblázat. A teljes random keresztellenőrzés legkisebb átlagos négyzetes eltérés (L-RMSE) a hozzá tartozó fökomponens/PLS komponens számmal, PCR és PLSR modellekben

Table III. The minimum root mean square error ( $L$ RMSE) of the complete randomized cross-validation is shown with the number of principal components/PLS components in PCR and PLSR models

\begin{tabular}{ccccc}
\hline & \multicolumn{2}{c}{ L-RMSE } & \multicolumn{2}{c}{ Komponensek száma } \\
& PCR & PLSR & PCR & PLSR \\
\hline A & 7,3 & 7,3 & 13 & 14 \\
N & 5,8 & 5,7 & 14 & 14 \\
1d & 8,0 & 8,9 & 10 & 9 \\
2d & 10,4 & 10,8 & 10 & 9 \\
N1d & 7,1 & 7,2 & 10 & 10 \\
N2d & 8,2 & 9,2 & 12 & 11 \\
\hline b-A & 7,6 & 7,5 & 13 & 13 \\
b-N & 5,8 & 5,9 & 14 & 13 \\
b-1d & 8,0 & 8,8 & 10 & 9 \\
b-2d & 10,4 & 10,8 & 10 & 9 \\
b-N1d & 6,5 & 7,1 & 10 & 10 \\
b-N2d & 8,6 & 9,7 & 12 & 11 \\
\hline c-NM & 7,3 & 7,3 & 19 & 16 \\
c-NM1d & 7,1 & 7,4 & 20 & 16 \\
\hline
\end{tabular}

összehasonlítva az összabszorbancia szerinti normalizálás ad jobb eredményt (2. ábra). A maximum abszorbancia szerint normalizált spektrumokkal és azok első deriváltjával végrehajtott keresztellenőrzés L-RMSE értéke gyakorlatilag megegyezik, továbbá a kezeletlen spektrumok és az összabszorbancia szerint normalizált és első derivált spektrumokkal alkotott modellek L-RMSE értéke is ugyanezt a 7\% körüli értéket veszi fel. Azonban fontos megemlíteni, hogy ennek az L-RMSE értéknek az eléréséhez a maximum abszorbancia szerint normalizált spektrumok esetében jóval több fókomponenst kell bevonni a modellbe, mint a kezeletlen és az összabszorbancia szerint normalizált és első derivált spektrumok felhasználásakor (III. táblázat).

Az optimális fơkomponens / PLS komponens szám 9 és 20 között változik, azaz mindegyik esetben több mint a sztenderd ásványok száma (III. táblázat). A PCR modellek kissé több főkomponenst igényelnek ugyanakkora mértékű variancia leírásához, mint a PLSR modellek. Ha a spektrum előkezelési múveleteket nézzük, akkor pedig minél több előfeldolgozási múveletet hajtunk végre, annál kevesebb fôkomponens/PLS komponens szám szükséges a modell LRMSE értékének minimalizálásához. A második deriváltakkal alkotott PLSR modellekben például látható, hogy a legkisebb átlagos négyzetes eltérés eléréséhez már 9 PLS komponens elég, de a modell minimum hibája ettôl még a többi modellhez képest nagyobb, és ha a modellezésbe további főkomponenseket vonunk be, az RMSE értéke tovább nő (2. ábra).

\section{A modellek értékelése}

A modellek közül a legjobb közelítést úgy tûnik, hogy akkor érjük el, ha összabszorbancia szerinti normalizálást hajtunk végre a spektrumokon, biztosítva ezzel azt, hogy azonos skálán szemléljük a spektrumokat (2. ábra). Ebból adódóan a normalizáció a csiszolatban történő transzmiszsziós mérésekhez hasonló vastagságkorrekciót ad az ATR spektrumokon, ahol a megmintázott vastagságot a behatolási mélység jelenti (Mirabella 2002). Szemben az összabszorbancia szerinti normalizálással, a többkomponensû mintáknál a maximum abszorbancia szerinti normalizálással valójában megváltoztatjuk az egyes alkotók relatív intenzitását, arányát, hiszen az egyes ásványok infravörös fényelnyelési érzékenysége eltérô, amely megnehezíti a mennyiségi becslést (JORDÁ et al. 2015). Emellett a mintában lévő ásványok mennyiségétől függôen változhat, hogy a spektrumon hol jelentkezik a maximum abszorbancia (3. ábra), amely így a spektrumon különböző maximum abszorbancia helyekkel rendelkező minták értékelésében zavart okozhat. Különösen indokolt az összabszorbancia szerinti normalizálás, ha különböző készülékeken, de azonos metódussal felvett spektrumokat szeretnénk összehasonlítani, hiszen ha más-más készüléken vettük fel a spektrumokat, vagy időben eltért a felvételezés, akkor az alkalmazott forrás által leadott teljesítmény — így a tényleges intenzitás — eltérô lehet. Ezért az összehasonlíthatóság érdekében a regressziós modellek felállítása előtt célszerú lenne összabszorbancia 
(a)

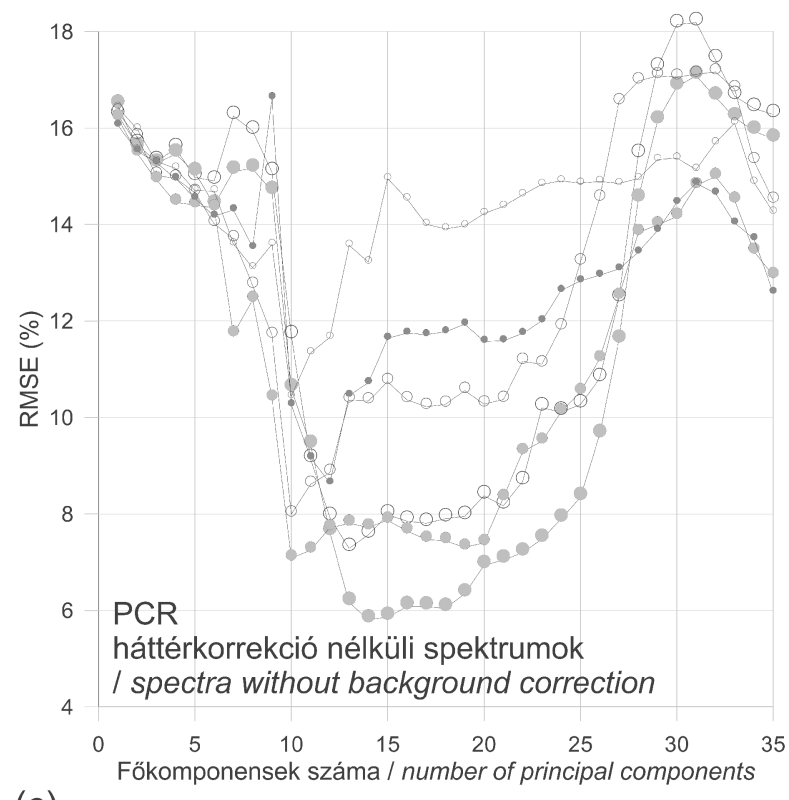

(c)

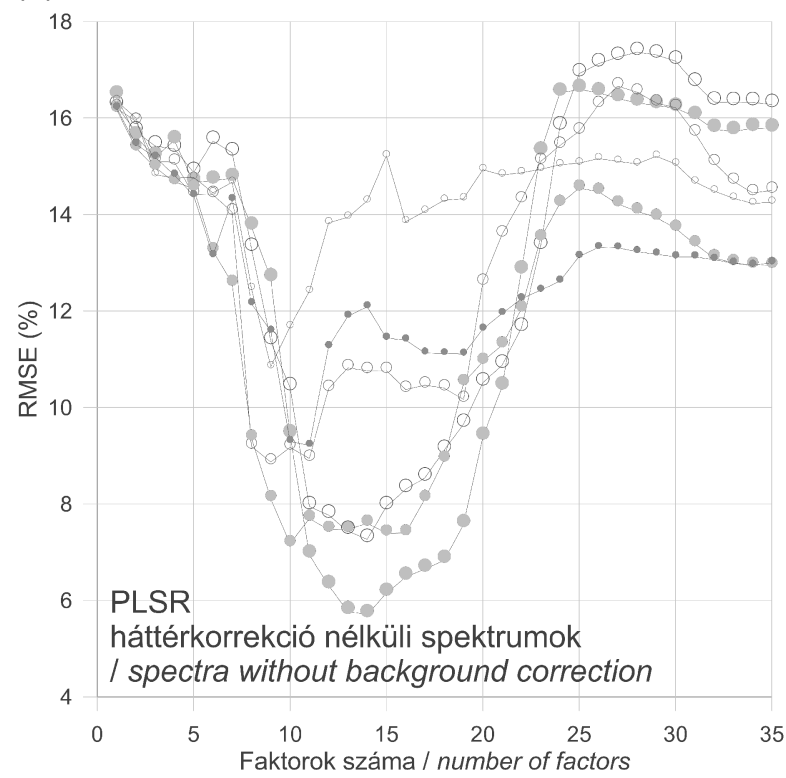

(b)

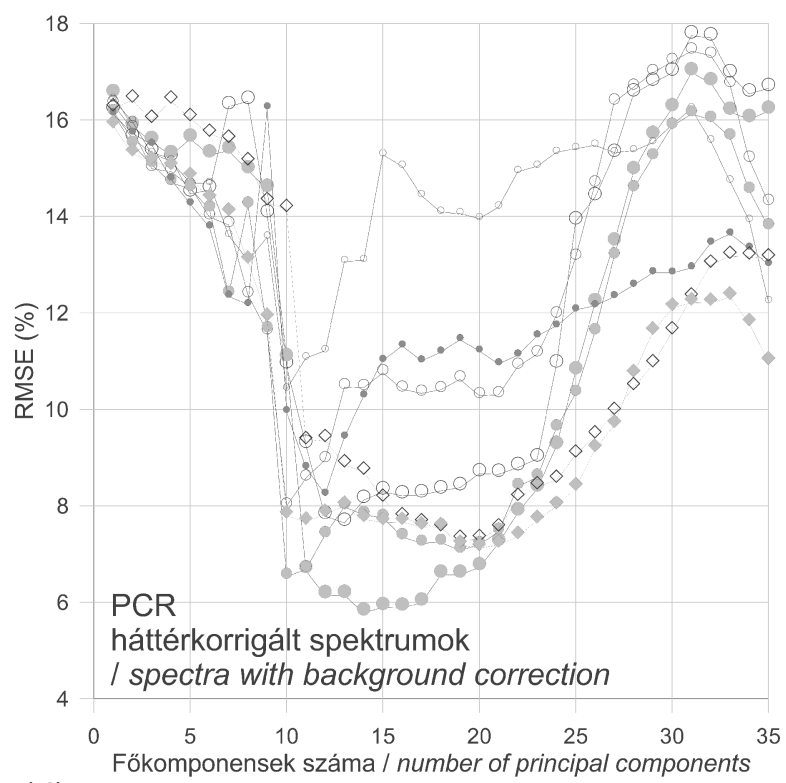

(d)

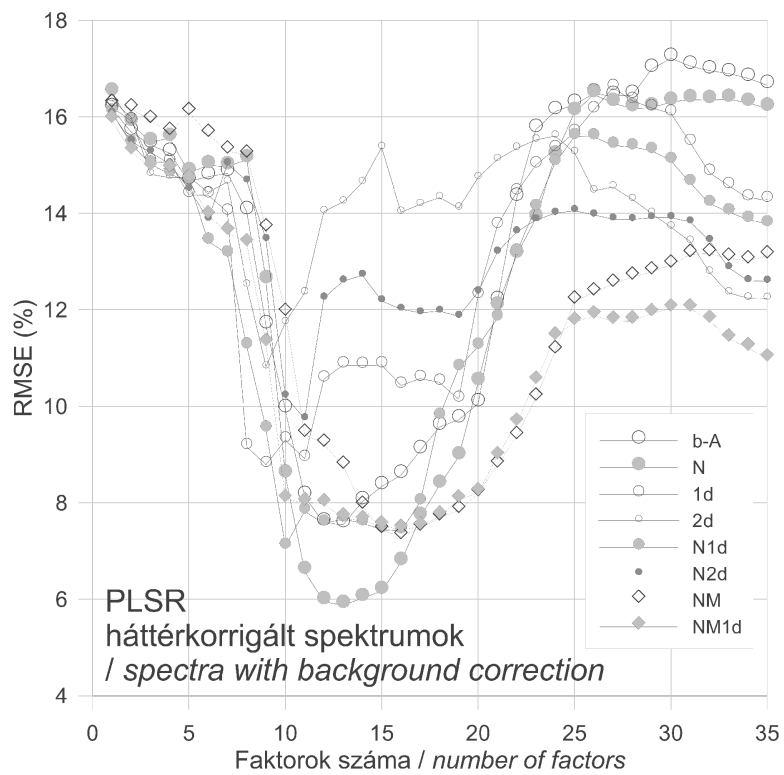

2. ábra. A teljes random keresztellenőrzés közepes négyzetes eltérése (RMSE, \%) a fökomponensek számának függvényében, PCR (a,b) és PLSR (c, d) modellben. A görbék elnevezése a különböző spektrumfeldolgozási módszerekre utal

Figure 2. The root mean square error (RMSE, \%) of the complete randomized cross-validation is shown with the number of principal components / PLS components in PCR $(a, b)$ and PLSR $(c, d)$ models. The names of the curves refer to the different pre-processing methods

szerint normalizálni a spektrumokat. További elókezelés az ismertetett mintákhoz hasonló anyagok esetében már nem szükséges, esetenként ronthatja a meghatározás jóságát (2. ábra, III. táblázat). Ha a spektrumok mégis deriválást igényelnek - nagyobb alapvonal-eltolódás vagy a minták nagyon különböző szemcseméretéből adódóan —, akkor előtte célszerú normalizálni, mert ezzel legalább csökkenthetô a becslés bizonytalansága, amit a deriválás által megnöveltünk. Természetesen ez a jelen feldolgozási metódusra érvényes, de ennek tesztelését akár nemlineáris algoritmusokra (pl. NIPALS) is elvégezhetjük. A L-RMSE értéke azonban ez esetben sem garantált, hogy csökkeni fog, mert a bemenő paraméterek is hordoznak magukban becslési bizonytalanságot.

Független meghatározási módszerként jelen esetben XRD-t használtunk, amely 3-5\%-os bizonytalansággal terhelt (Hillier 2000). Valószínúleg ezért sem sikerült $5 \%$ alá szorítani a modellek becslési hibáját. Ezért érdemes nemcsak XRD-t, hanem más analitikai módszert - pl. termogravimetria szerinti tömegszázalékos vagy részletesebb, szemcseszám szerinti ásványösszetételt - is bevonni az ásványmennyiségek becslését célzó modellek felállításakor. A legegyszerúbb megoldás jelen esetben, ha a mérlegen bemért mintatömegekkel is összevetjük a becsült ásvány- 
(a)

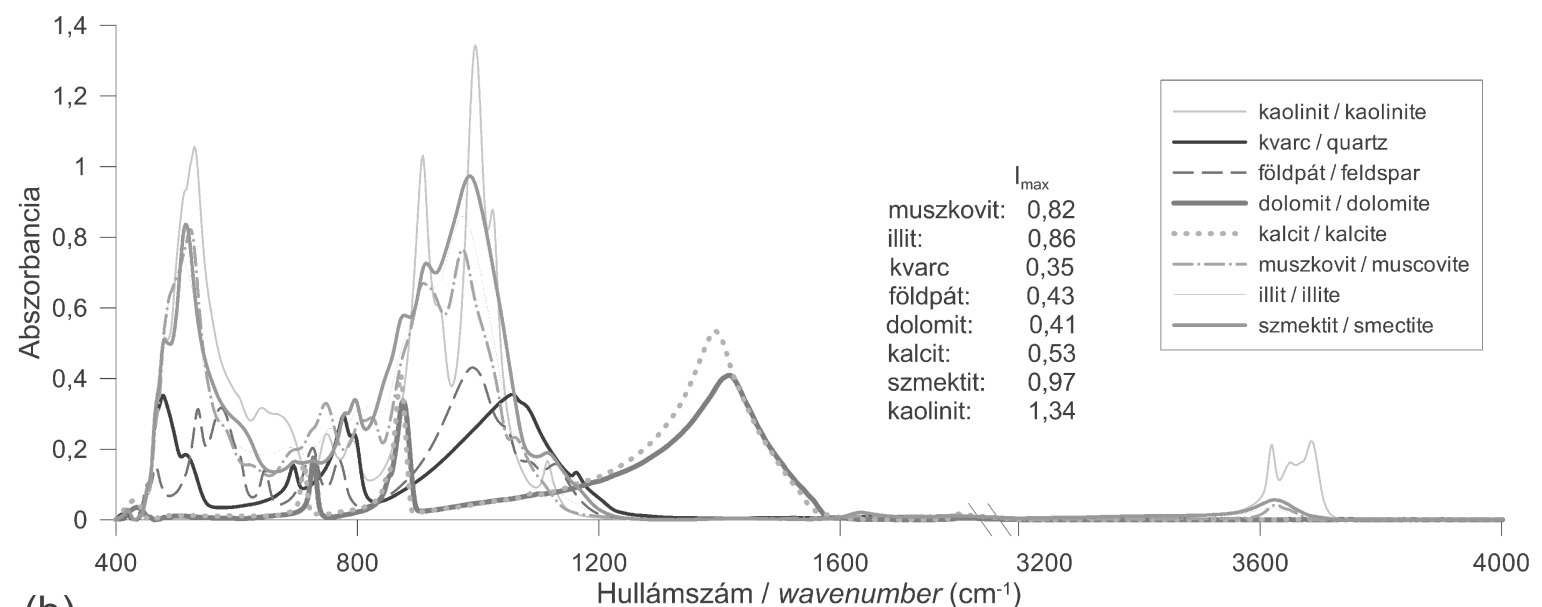

(b)

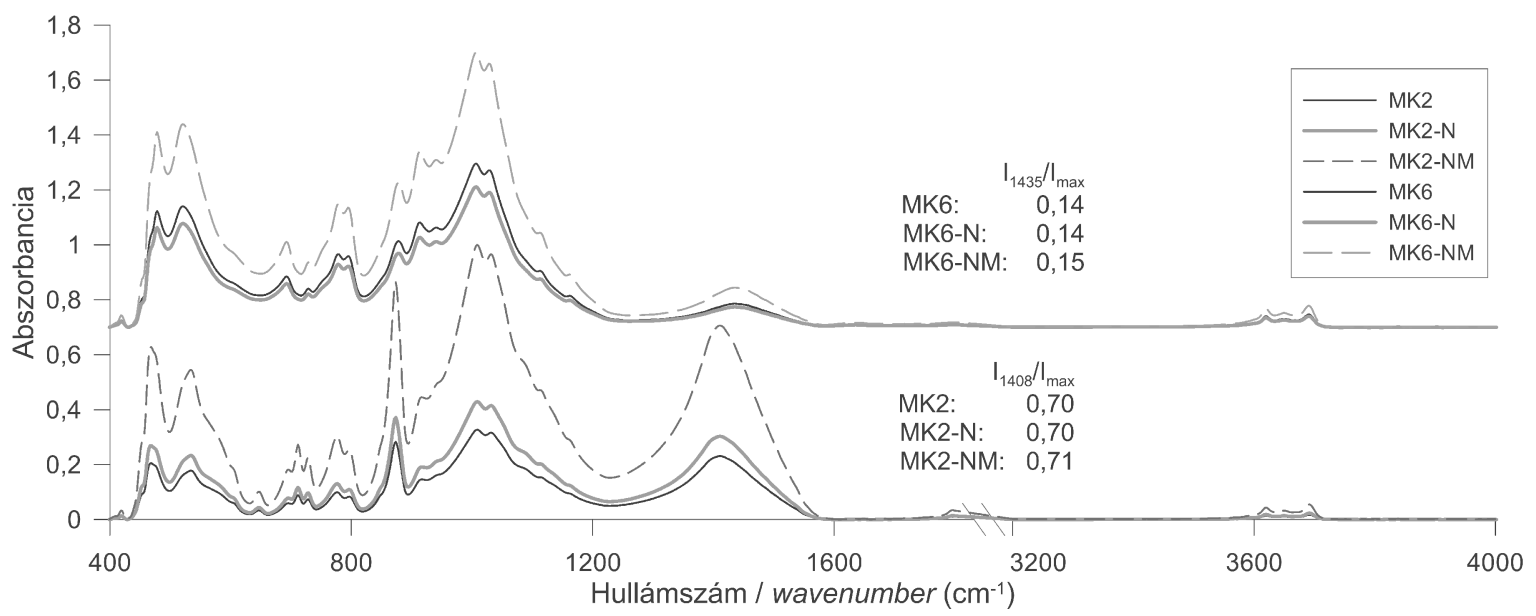

3. ábra. Az ásványok infravörös fényelnyelése a természetes sztenderdekben (a) és a szintetikus ásványkeverékekben (b). Megfigyelhető, hogy a maximális abszorbancia $\left(\mathrm{I}_{\max }\right)$ nagysága ásványfüggő. Két ásványkeverék infravörös spektrumának (MK2, MK6) eredeti, összabszorbancia (N) és maximum abszorbancia $(\mathrm{NM})$ szerint normalizált spektrumát is feltüntettük, illetve a karbonátok karakterisztikus sávmaximuma $\left(\mathrm{I}_{408} \mathrm{I}_{1435}\right)$ és a maximum intenzitás hányadosát

Figure 3. The absorption of the infrared light by natural standards (a) and synthetic mixtures $(b)$ is illustrated. Value of the maximum absorbance ( $\left.I_{\text {max }}\right)$ depends on the type of minerals. Original spectra, and total absorbance $(N)$ and maximum absorbance (NM) normalized spectra of two mineral mixtures (MK2, MK6) are shown. Ratios of the characteristic peaks of carbonates $\left(I_{1408}, I_{1435}\right)$ and $I_{\text {max }}$ are also indicated

mennyiségeket. Valójában azonban ezzel a sztenderd menynyiségét határozzuk meg és nem pusztán egy ásvány menynyiségét, amely gyakorlati szempontból értelmetlen, ha ásványok mennyiségét szeretnénk becsülni. Az XRD-vel mért és a mérlegen bemért ásványok tömegszázalékos mennyisége között mindenesetre igen kis különbségeket tapasztal- tunk, amelyet a két érték közötti determinációs együttható nagysága is jól szemléltet (IV. táblázat). A másik ok, amely az ásványmennyiségek meghatározásának bizonytalanságát jelentősen befolyásolhatja, hogy a minták az XRD módszer alapján néhány százalékban olyan ásványfázisokat (klorit, anatáz, kevert szerkezetek) és amorf anyagot is tartalmaz-

IV. táblázat. A determinációs együttható $\left(\mathrm{R}^{2}\right)$ az ásványok XRD-vel meghatározott és a mérlegen bemért természetes sztenderdek mennyisége közötti kapcsolatot jellemzi, modelltagokra $\left(R_{1}^{2}\right)$ : MK1-31 és teszt mintákra $\left(R_{2}^{2}\right)$ : MK32-41. Y1 és Y2 a regressziós egyenes y tengelymetszetét mutatja

Table IV. Coefficient of determination $\left(R^{2}\right)$ is shown the relationship between amounts of minerals detected by XRD and the percentages of natural standards prepared by weighing in the synthetic mixtures, for the model set $\left(R_{1}^{2}\right): M K 1-31$ and the test set $\left(R_{2}^{2}\right): M K 32-41 . Y 1$ and $Y 2$ indicate the $y$-intercept of the regression line

\begin{tabular}{ccccccccc}
\hline Elnevezés & Muszkovit & Illit & Kvarc & Földpát & Dolomit & Kalcit & Szmektit & Kaolinit \\
\hline $\mathrm{R}_{1}^{2}$ & 0,999 & 0,993 & 0,994 & 0,996 & 0,998 & 0,998 & 0,979 & 0,997 \\
$\mathrm{Y} 1$ & $-0,20$ & $-0,60$ & $-0,09$ & 0,10 & $-0,50$ & 0,14 & $-1,21$ & $-0,51$ \\
\hline $\mathrm{R}_{2}^{2}$ & 0,999 & 0,999 & 0,947 & 0,998 & 0,999 & 0,999 & 0,965 & 0,998 \\
$\mathrm{Y} 2$ & $-0,05$ & 0,02 & $-3,31$ & 0,39 & $-0,09$ & $-0,38$ & $-0,68$ & $-0,18$ \\
\hline
\end{tabular}


nak, amelyekre vagy nem rendelkezünk kalibrációval vagy infravörös inaktivitásuk miatt nem lehetséges azonosításuk az infravörös spektrumon (I. táblázat). Azaz valójában több komponens van a mintákban - látens változóként -, mint ahányra a modellt szeretnénk felállítani. Ezért is több a modellek optimális fôkomponensszáma, mint a sztenderdekként definiált ásványok száma (III. táblázat). A modellezéshez szükséges főkomponensek száma ilyen típusú modellezéseknél tehát árulkodik arról, hogy hány komponenst, tulajdonságváltozót nem ismerünk. A tárgyalt bizonytalansági faktorok tükrében az L-RMSE értékét esetenként csökkenthetjük — ha a megválasztott módszer indokolja — például a kalibrációs modell bővítésével, kiegészítve egyéb komponensekkel.

\section{A modellek tesztelése: ásványok becslési bizonytalansága a modellekben}

A 38 db spektrumból a 8 db ásványalkotóra felállított PCR és a PLSR modellekkel 10 db szintetikus ásványkeverék modális összetételét is megbecsültük annak érdekében, hogy egy validáló adatsoron ásványonként is szemléltessük a különböző módon előkezelt spektrumokkal végzett becslések közötti hasonlóságokat és különbségeket. Ennek szemléltetése céljából a becsült mennyiségi adatokra lineáris trendvonalat illesztettünk és vizsgáltuk annak determinációs együtthatóját, meredekségét és tengelymetszetét (1. később 5-7. ábra, 2. és 3. digitális melléklet). E paraméterek értelmezésénél azzal a megközelítéssel élhetünk, hogy minél jobban közelíti az adott ásvány XRD-vel meghatározott mennyiségét a becsült mennyiség — azaz az $\mathrm{R}^{2}$ és a meredekség 1-hez, a tengelymetszet 0-hoz tart —, annál jobb az alkalmazott modell, illetve spektrumfeldolgozás ( $\mathrm{R}^{2}$ szignifikanciájának vizsgálatát a 4. digitális melléklet tartalmazza). Emellett azonban még két tényezôt kell figyelembe venni. Az egyik, hogy bár egy ásvány becsült menynyisége jó összefüggést mutathat az XRD adatokkal, determinációs együtthatója nagy lehet, de a tárgyalt infravörös fénnyel szembeni érzékenysége miatt előfordulhat, hogy például fele akkora mennyiségben becsüljük, mint az XRD által detektálható mennyisége, így a mért és becsült paraméter kapcsolatát leíró trend meredeksége nem 1 értékú lesz. A másik lényeges pont, ha a kimutatási határ nem azonos a két módszernél (1. részletesen ásványokra JoRDÁ et al. 2015), az általuk definiált trend tengelymetszete nem 0 értékű lesz. Ekkor a trendvonal alsó tartománya ,görbül”, a tengelymetszet negatív vagy pozitív értékú, illetve a kis mennyiségeknél az adatok szórása nagy lehet. Éppen ezért a lineáris trendvonalakat nem 0 értékben illesztettük.

A PCR és a PLSR modellezést az összes főkomponens és a keresztellenőrzés eredményében mutatkozó optimális fôkomponensszámmal (III. táblázat) is elvégeztük. Úgymint a keresztellenőrzésben, itt sem mutatkozik érdemi különbség a PCR és a PLSR modellek között (4. ábra). A teljes főkomponensszámmal, a két modellalkotási eljárásban becsült mennyiségek hat tizedesjegyig megegyeznek, míg a csökkentett főkomponensszámmal kissé nagyobbak a (a)

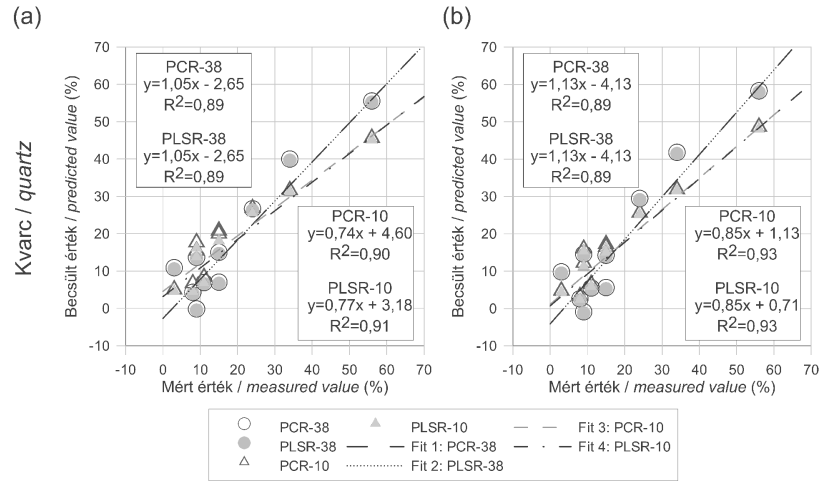

4. ábra. b-N1d (a) és N1d (b) feldolgozású spektrumokon a PCR és a PLSR modellekkel becsült kvarc mennyisége, teljes (38) és a keresztellenőrzés eredménye alapján optimalizált (10) főkomponensszámmal

Figure 4. Predicted amounts of quartz are illustrated using b-N1d-(a) and N1dprocessed (b) spectra in PCR and PLSR models. All principal components (38) and their optimized numbers by cross-validation (10) are used for the PCR and PLSR models

két modell becslése közötti különbségek. Ez utóbbi esetben nem a modellek eltérô főkomponensszámából ered a különbség, mert ott is van eltérés a becsült értékekben, ahol azonos volt az optimális főkomponensszám (4. ábra). Az eredményekből az is kitûnik, hogy a spektrumfeldolgozási múveletek jobban befolyásolják a becsült ásványmennyiségeket (4. és 5-7. ábra), mint a választott többváltozós regresszió (PCR vagy PLSR). Ugyanakkor az is látható, hogy a háttérkorrekció és annak hiánya a becslésre minimális hatással van (4. ábra a, $b$ ), ezért a továbbiakban a PCR modellben, a spektrumok feldolgozási múvelete szerint, csak a háttérkorrigált felvételekből kiindulva szemléltetjük a becsült ásványmennyiségeket (5-7. ábra), a további részleteket a 2. és 3. digitális mellékletekben közöljük.

Ha a becsült mennyiségekre illesztett lineáris trendvonalat megfigyeljük ásványonként, látható, hogy a meredekség 1-hez közeli értéket vesz fel (5-7. ábra, 2. és 3. digitális melléklet). Előfordul azonban, hogy az XRD-vel mért és becsült mennyiségek képzeletbeli 1:1 egyeneséhez képest eltér a trendvonal meredeksége - elsősorban az illitnél, szmektitnél és földpátnál (5. és 6. ábra). Ez esetben az Y tengelymetszet értéke is széles tartományban változik a különböző spektrumfeldolgozásoknál, ezért az illesztett egyenes meredeksége igen eltérô lehet feldolgozási módszerenként (5. és 6. ábra, 2. és 3. digitális melléklet). A nagyfokú változékonyság egyúttal arra is utalhat, hogy azonos mennyiségeket, de különbözô ásványokat különbözô érzékenységgel becsülhetünk. Ha megfigyeljük az Y tengelymetszet értékét, látható, hogy mely ásványokat határozunk meg jobb vagy éppen rosszabb kimutatási határral, mint XRD-vel. Ez az egyes ásványok különbözô infravörös fényelnyelő képességével magyarázható, amelynek következtében az ásványok spektrumában a karakterisztikus sávok intenzitása azonos ásványmennyiség mellett is eltérô lesz (3. ábra). A különböző modelleket vizsgálva ugyanakkor pozitív és negatív tengelymetszetek is előfordulnak, ezért egyértelmúen nem állapítható meg, hogy melyik módszer lesz ideális a kis mennyiségek 

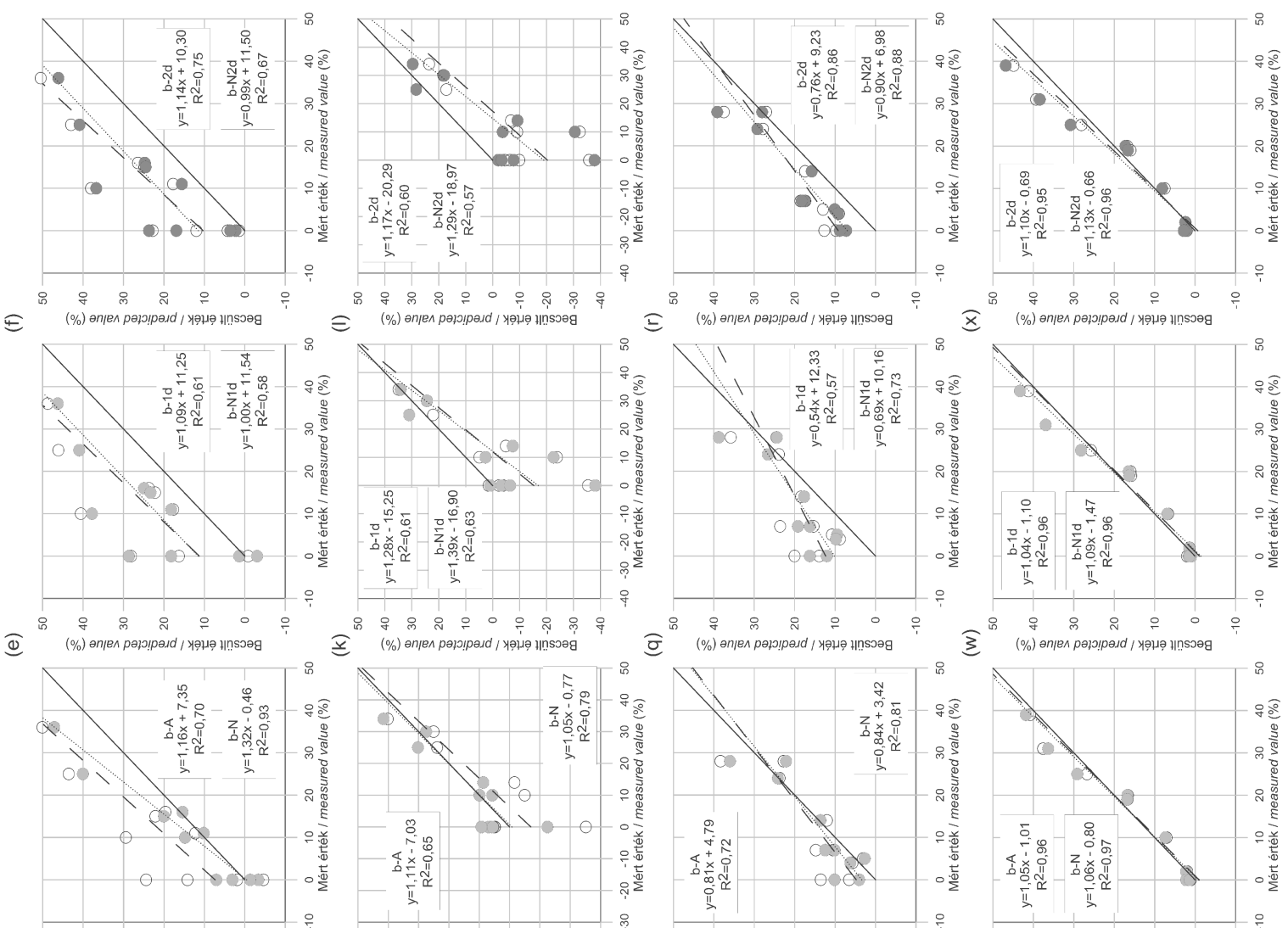

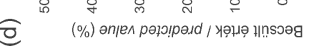
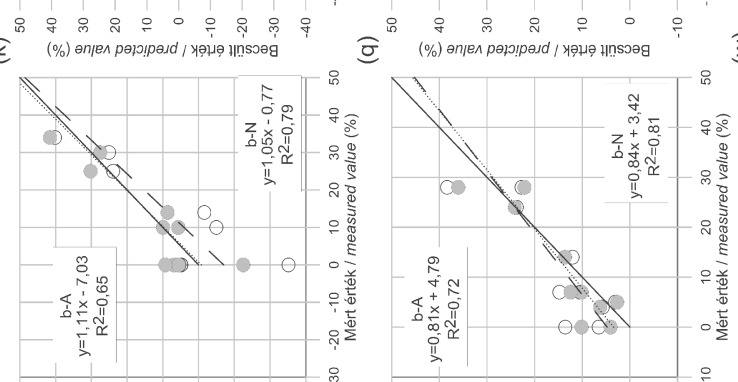

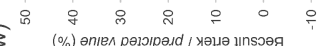
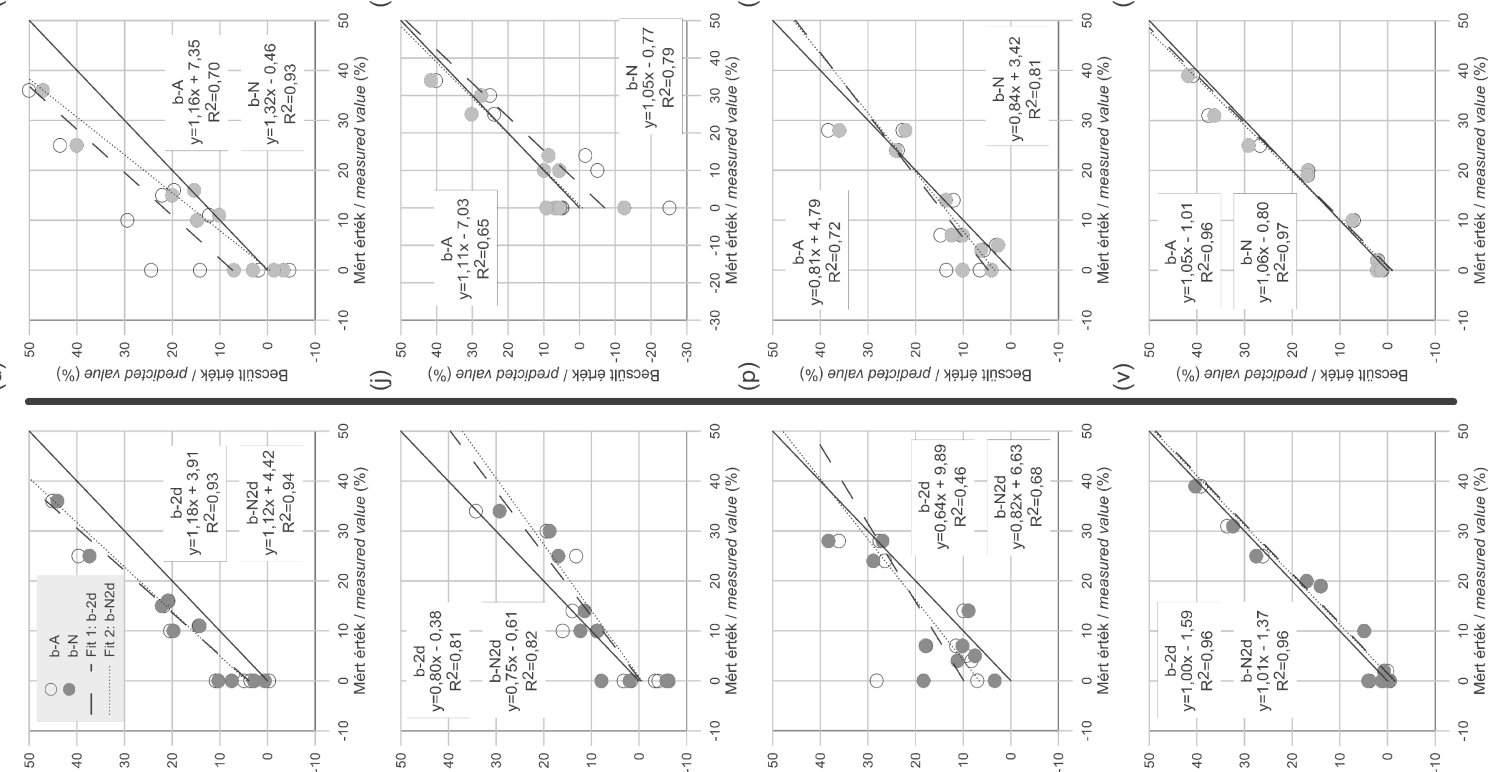

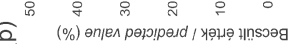

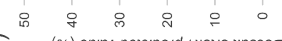
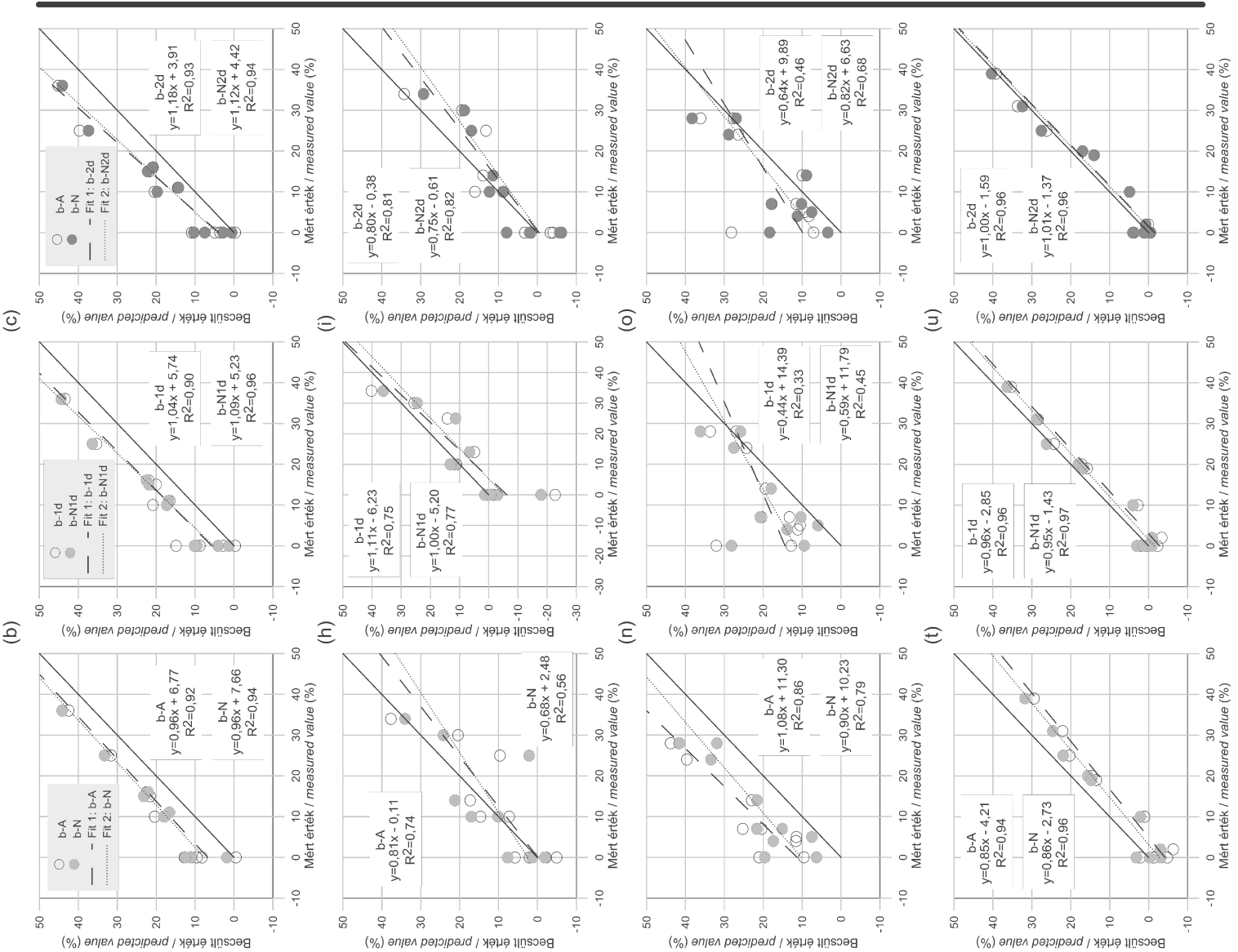

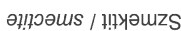

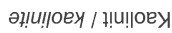



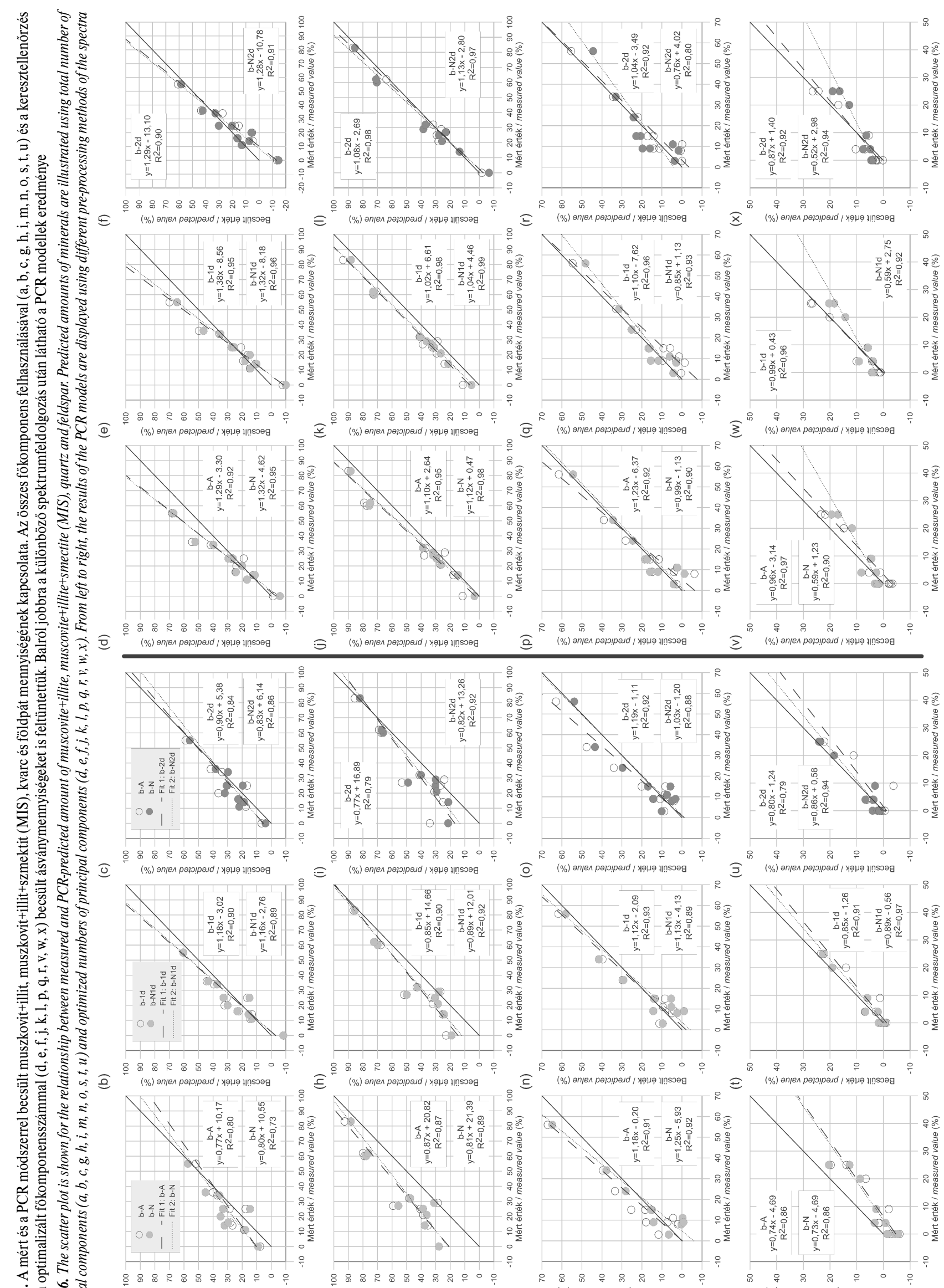
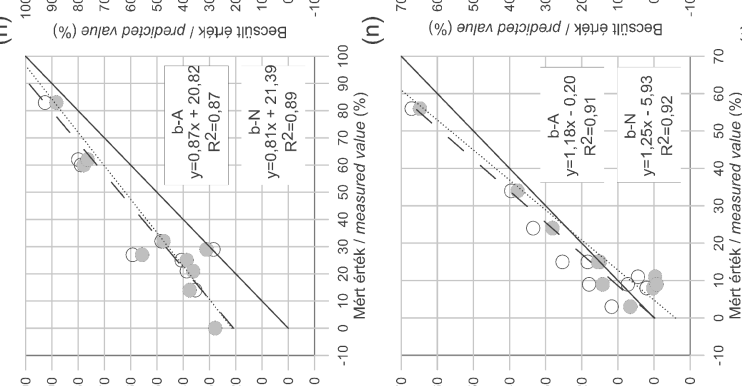

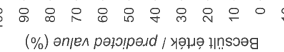

SIW

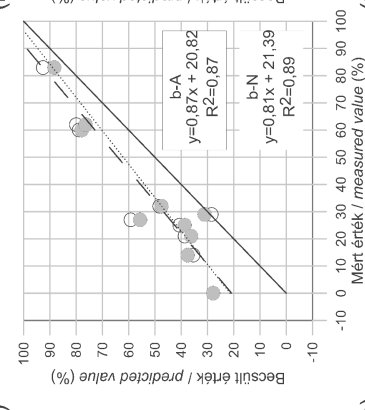

$\widehat{\underline{\xi}}$

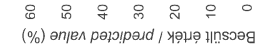

zдеnb / गел다
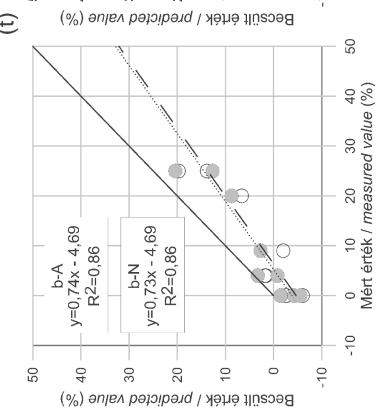

(n)

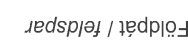



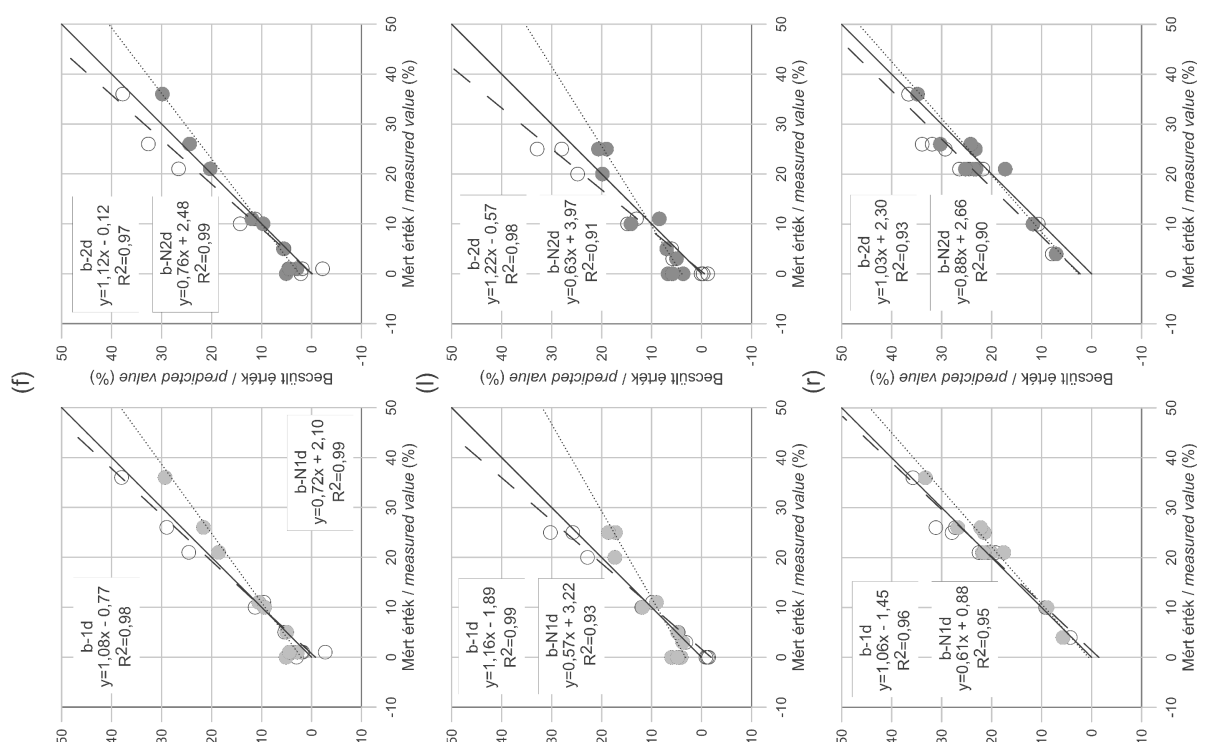

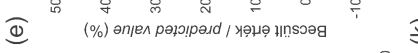

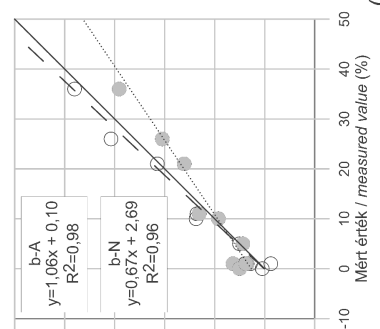

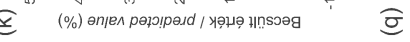

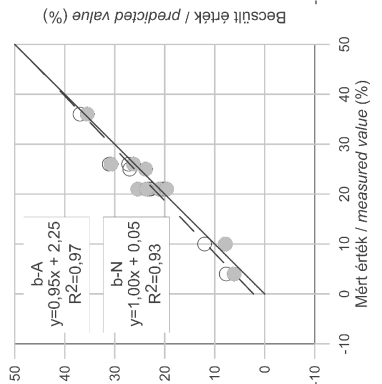

흐
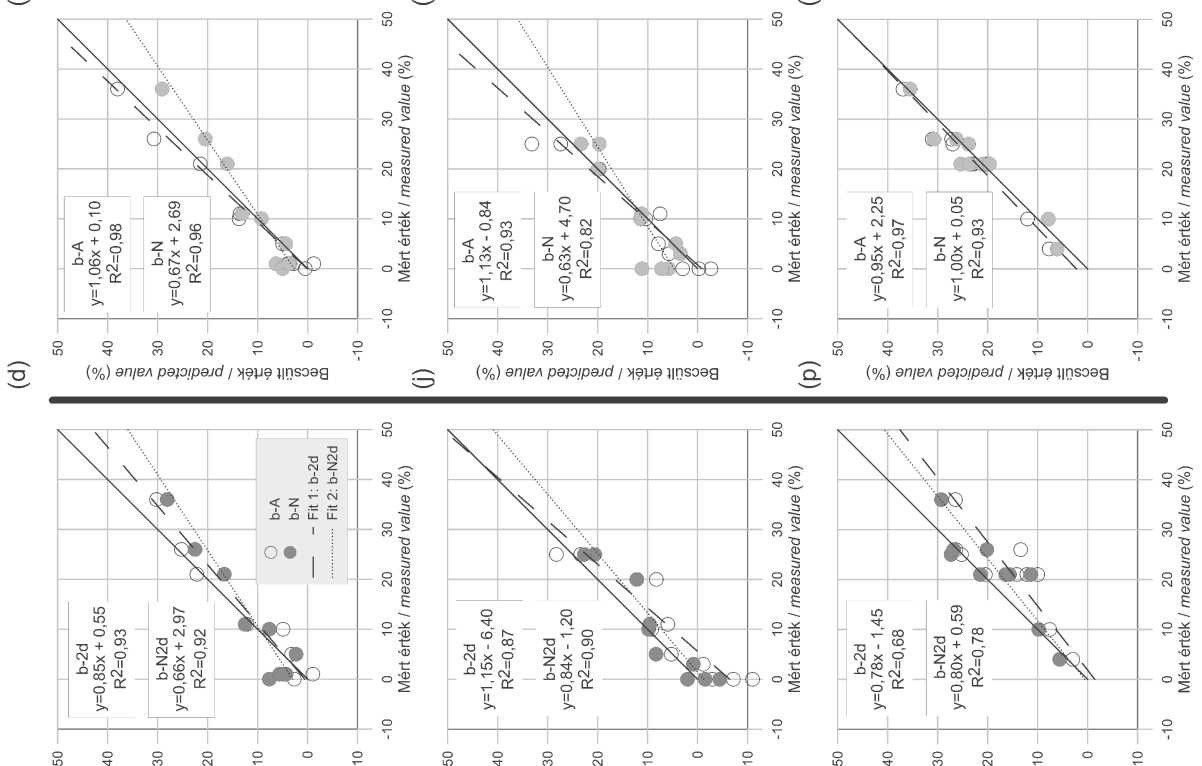

(3)
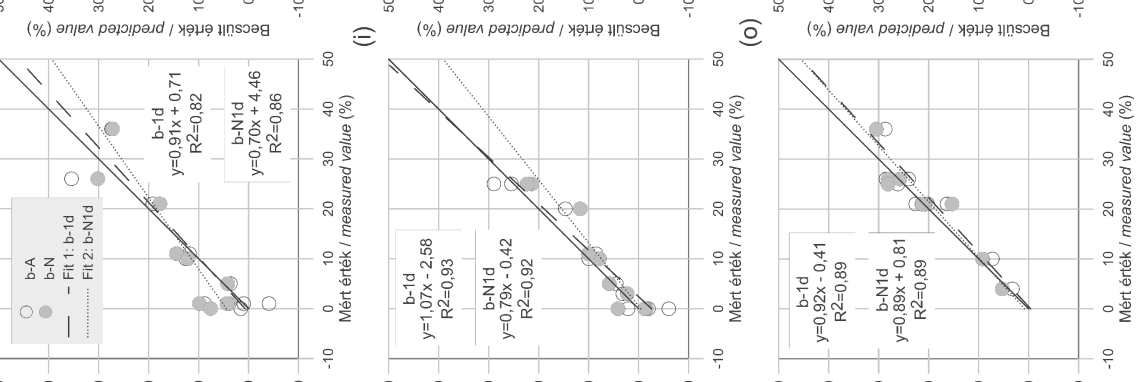

을

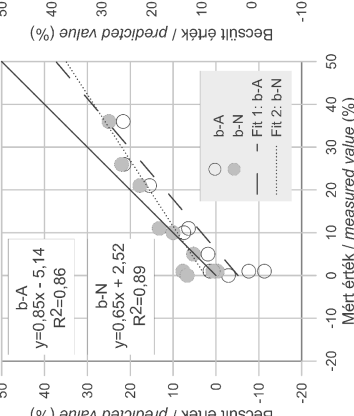

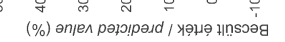

$\underbrace{\circ}$

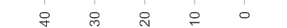

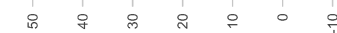
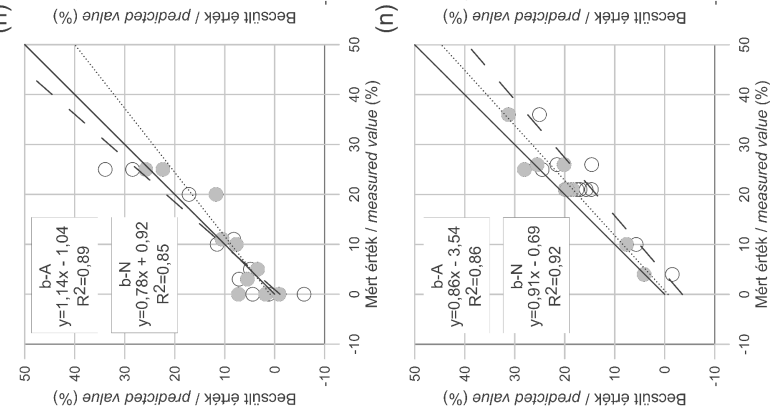
vizsgálatához. Ennek további megfigyeléséhez számos más tényezốt is figyelembe kell venni, ilyen például az ásványok infravörös fényelnyelő képességén túl kitüntetetten a szemcseméret (UDVARDI et al. 2016). Ez nyújthat magyarázatot arra, hogy a különböző spektrumfeldolgozási múveletek közül a legjobb illeszkedést a keresztellenôrzés eredményéhez képest a tesztmintákon miért is már nem egyértelmúen a normalizált spektrumok adják. Ez arra utalhat, hogy önmagában valójában nem elég a spektrumok összabszorbancia szerinti normalizálása (5-7. ábra).

A legtöbb modellben rendre nagyobb bizonytalansággal becsüljük a döntôen finom szemcsemérettel jelentkező ásványokat, az illitet, muszkovitot és szmektitet. Az illit és a szmektit sokszor alkot kevert szerkezetet, amely okozhat becslési bizonytalanságot (MÜLLER et al. 2014). Jelen esetben azonban ezt az ásványos összetétel nem igazolja ( $I$. táblázat, CHIPERA \& Bish 2001). Inkább azzal magyarázható, hogy a többkomponensú keverékekben az infravörös sávjaik átfednek, nincs karakterisztikus elkülönítő bélyegük. Valószínúleg ez okozza a nagy negatív vagy pozitív értékú becsült mennyiségüket olyan mintákban is, amelyekben nem kimutatható az adott módszerrel (5. ábra). Emellett megemlítendô még, hogy a becslési bizonytalanságot a szmektit esetében az is okozhatja, hogy a mérlegen bemért és az XRD-vel határozott mennyiségek között nagyobb a különbség a többi ásványhoz viszonyítva. Ugyanez jelentkezhet a kvarc mennyiségében is, fóleg a $10 \%$ körüli és annál kisebb mennyiségeknél (6. ábra). A három ásvány muszkovit, szmektit, illit — vagy a muszkovit+illit összege ugyanakkor esetenként jobb összefüggést mutat, mint külön-külön (5. és 6. ábra). Ennek következménye, hogy célszerú a muszkovitot, illitet és szmektitet együtt kezelni a többváltozós modellekben. A karbonátokat is hasonló módon összevonhatjuk, azonban a spektrumon a dolomit karakterisztikus sávmaximumai a Mg-tartalma miatt más hullámszámnál jelentkeznek a kalcithoz képest, ezért önmagában is jobban elkülöníthetô, becsülhető a kalcit jelenléte mellett, mint a muszkovit, illit, szmektit (7. ábra).

A legjobban becsülhetô ásvány az XRD adatokhoz viszonyítva a kaolinit (5. ábra). Ebben szerepet játszhat az, hogy az egyik legerősebb infravörös abszorbanciával rendelkezik a vizsgált ásványok közül és infravörös sávjai kevésbé fednek át más ásványokkal, ellentétben a muszkovittal, illittel és szmektittel (3. ábra). Továbbá az erôs abszorbanciája magyarázza azt is, hogy a kaolinit mindegyik modellben, spektrum-feldolgozási múvelettól függetlenül jól becsülhetô (5. ábra). Az egyes modellek között a becsült kaolinit mennyiségekre illesztett egyenes determinációs együtthatóinak szórása szúk tartományon belül változik ( 2 . és 3. digitális melléklet). Ugyanez figyelhetố meg a földpátnál is, viszont a becsült mennyisége rendre kisebb, mint az XRD-vel mért (6. ábra, 2. és 3. digitális melléklet). A földpát összabszorbanciája ugyan kevesebb, mint fele a kaolinitének, de ez önmagában nem indokolja az alulbecslést, mert a kvarc is hasonló összabszorbanciával rendelkezik, mint a földpát, mégsem becsüljük alul (3. ábra). Felvetődik annak lehetôsége, hogy a többváltozós módsze- rekkel becsült ásványmennyiségek becsült értéke fizikai tulajdonságokra is visszavezethető, például mátrixhatásra, azaz hogy milyen ásványokkal együtt fordul elő egy-egy ásvány és azoknak mi a szemcsemérete. Ennek magyarázata viszont további vizsgálatokat igényel.

Az egyes ásványok becslési bizonytalanságát a tárgyalt tényezőkön kívül az is befolyásolhatja, hogy az összetételben a 8 vizsgált ásványon kívül előforduló egyéb alkotókat nem vettük figyelembe a modellekben, ezért nem $100 \%$-os összetételi adatokkal dolgoztunk (I. táblázat). A becsült összetételi adatok összmennyisége azonban láthatólag jól mutatja, hogy a 8 fázison kívül egyéb alkotókat is tartalmazhat. Ez esetben a becsült összmennyiség 100\%-nál kevesebb

V. táblázat. A vizsgált ásványok összmennyisége az XRD módszerrel és a becsült minimum, maximum és átlagos összmennyiség a modellekben

Table V. Results show total amount of the observed minerals studied by $X R D$ and the predicted minimum, maximum and average amount in the models

\begin{tabular}{ccccc}
\hline Minta & XRD \% & MIN & MAX & AVG \\
\hline MK32 & 100 & 99,4 & 102,0 & 100,2 \\
MK33 & 100 & 96,8 & 102,5 & 99,8 \\
MK34 & 100 & 95,4 & 104,0 & 100,4 \\
MK35 & 100 & 99,1 & 100,6 & 100,0 \\
MK36 & 96 & 95,0 & 99,5 & 98,3 \\
MK37 & 96 & 92,6 & 98,6 & 97,4 \\
MK38 & 99 & 98,7 & 100,5 & 99,3 \\
MK39 & 96 & 94,4 & 98,2 & 97,0 \\
MK40 & 97 & 97,8 & 100,3 & 99,5 \\
MK41 & 97 & 95,2 & 100,0 & 99,0 \\
\hline
\end{tabular}

lesz, így a becslési modell alapján arról is kaphatunk információt, hogy egyéb fázisok is előfordulhatnak a mintában (V. táblázat).

\section{Összefoglalás}

A többváltozós adatelemzéssel kombinált ATR FTIR módszer lehetôvé teszi ásványmennyiségek becslését, azonban alkalmazásához számos körülményt kell megvizsgálni. Az üledékes kôzetekben gyakori ásványok természetes referenciaanyagain — kalcit, dolomit, kvarc, földpát, muszkovit, illit, szmektit, kaolinit — és azok keverékéből alkotott mintákon végzett elemzések alapján ásványkeverékek becslésére mind a fő́komponens-regresszió, mind pedig a parciális legkisebb négyzetek regresszió ugyanúgy használható, lényeges különbség a két módszer eredménye között nem mutatkozik. A modellben alkalmazott spektrumok feldolgozási múveleteire azonban annál inkább ügyelni kell. Az ásványkeverékek, kőzetek ilyen jellegú vizsgálatában nincs általánosan elfogadott módszer, de a jelenlegi tapasztalataink azt mutatják, hogy esetenként célszerú összabszorbancia szerint normalizált spektrumokkal dolgozni, és kerülendô a maximum abszorbancia szerinti normalizálás. Emellett célszerú a modell spektrum adatainak teljes random keresztellenôrzését elvégezni — amennyiben a kombinációk száma lehetôvé teszi — annak eldöntésére, hogy mekkora kezdeti hibával kell számolnunk, mennyi kompo- 
nens szükséges a minél pontosabb becsléshez, van-e látens változó, és ezek alapján, ha lehetséges, a modellt tovább finomíthatjuk.

Az XRD-vel meghatározott és a felállított modellek alapján becsült ásványmennyiségek összevetéséből kitűnik, hogy az üledékes kôzetekben gyakori ásványok közül a modellekben a kaolinit becsült mennyisége önállóan is jó egyezést mutat az XRD-vel mért adatokkal, amely azzal magyarázható, hogy az egyik legerôsebb infravörös abszorbanciával rendelkezik a vizsgált ásványok közül és infravörös sávjai kevésbé fednek át más ásványokkal, ellentétben a muszkovittal, illittel és szmektittel. A muszkovit, illit és szmektit mennyiségére vonatkozóan a regressziós modellekben célszerü összmennyiségi becsléseket végezni az átfedő infravörös sávjaik miatt. A földpát és kvarc XRD módszerrel és regressziós modellek segítségével meghatározott mennyisége jól szemlélteti, hogy a becslést a mennyiségi viszonyokon, sávátfedéseken kívül a fizikai tulajdonságok is befolyásolhatják (pl. szemcseméret, mátrixhatás).

\section{Köszönetnyilvánítás}

Ezúton szeretnénk köszönetet mondani KovÁcs Józsefnek a kézirat alapos bírálásáért és az építő jellegú megjegyzéseiért, valamint SzTANó Orsolyának és PIROs Olgának a szerkesztôi munkájukért, melyekkel hozzájárultak a kézirat végleges formába öntéséhez.

\section{Irodalom - References}

ADAMU, M. B. 2010: Fourier Transform Infrared Spectroscopic Determination of Shale Minerals in Reservoir Rocks. — Nigerian Journal of Basic and Applied Science 18, 6-18. https://doi.org/10.4314/njbas.v18i1.56836

BertauX, J., FRÖHLICH, F., ILdEFOnSE, P. 1998: Multicomponent analysis of FTIR spectra: quantification of amorphous and crystallized mineral phases in synthetic and natural sediments. - Journal of Sedimentary Research 68/3, 440-447. https://doi.org/10.1306/ d42687cf-2b26-11d7-8648000102c1865d

BRUKER OPTIK 2011: IR Reference Manual. — Opus Spectroscopy Software, Ettlingen, Germany, 120 p.

ChIPERA, S. J. \& Bish, D. L. 2001: Baseline studies of The Clay Minerals Society Source Clays: Powder X-ray diffraction analyses. Clays and Clay Minerals 49, 398-409. https://doi.org/10.1346/ccmn.2001.0490507

DE Jong, S. 1993: SIMPLS: An alternative approach to partial least squares regression. Chemom. — Chemometrics and Intelligent Laboratory Systems 18, 251-263. https://doi.org/10.1016/0169-7439(93)85002-x

DUYCKAERTS, G. 1959: The infrared analysis of solid substances. - Analyst 84, 201-214.

EATON, J. W., BATEMAN, D., HAUBERG, S., WehBRING, R. 2015: GNU Octave version 4.0.0 manual: a high-level interactive language for numerical computations. [http://www.gnu.org/software/octave/doc/interpreter - 2017.06.10.]

Geladi, P. \& KowALSKI, B. R. 1986: Partial least-squares regression: A tutorial. — Analytica Chimica Acta 185, 1-17. https://doi.org/ 10.1016/0003-2670(86)80028-9

GemPerline, P. 2006: Chapter 4: Principal component analysis. - GemPerline, P. (ed.): Practical Guide To Chemometrics, $2^{\text {nd }}$ ed., Boca Raton, CRS Press, Taylor \& Francis Group, 552 p. ISBN: 1420018302. https://doi.org/10.1201/9781420018301

Griffiths, P. R. \& De Haseth, J. A. 2007: Chapter 10: Data Processing. — Griffiths, P. R. \& De HASETH, J. A. (eds): Fourier Transform Infrared Spectrometry, $2^{\text {nd }}$ ed., New York, Wiley-Interscience, 225-250. https://doi.org/10.1002/9780470106310.ch10

HenRY, D. G., WATson, J. S. \& John, C. M. 2017: Assessing and calibrating the ATR FTIR approach as a carbonate rock characterization tool. - Sedimentary Geology 347, 36-52. https://doi.org/10.1016/j.sedgeo.2016.07.003

HILLIER, S. 2000: Accurate quantitative analysis of clay and other minerals in sandstones by XRD: comparison of a Rietveld and a reference intensity ratio (RIR) method and the importance of sample preparation. - Clay Minerals 35, 291-302. https://doi.org/ $10.1180 / 000985500546666$

Jordá, J. D., Jordán, M. M., Ibanco-Cańete, R., Montero, M. A., Reyes-Labarta, J. A., SÁnchez, A. \& Cerdán, M. 2015: Mineralogical analysis of ceramic tiles by FTIR: a quantitative attempt. - Applied Clay Science 115, 1-8. https://doi.org/10.1016/ j.clay.2015.07.005

KLUG, H. P. \& AleXANDER, L. E. 1954: X-ray diffraction procedures. — John Wiley Sons Inc., New York-London-Párizs, 716 p.

KovÁcs, J \& KovÁcsné SzÉKelY, I. 2006: A minta értelmezési problémái: elmélet és gyakorlat. — Földtani Közlöny 136/1, $139-146$.

Kovács I., Udvardi B., Falus Gy., Földvári M., Fancsik T., Kónya P., Bodor E., Mihály J., Németh Cs., CzirJák G., Ősi A., VargáNÉ BARNA Zs., BHATTOA H., SzEKANECZ Z. \& TURZA S. 2015: Az ATR FTIR spektrometria gyakorlati alkalmazása néhány — elsősorban földtani — esettanulmány bemutatásával. — Földtani Közlöny 145/2, 173-192. http://ojs3.mtak.hu/index.php/foldtanikozlony/ article/view/116

Martens, H. S. \& NAES, T. 1989: Multivariate Calibration. — John Wiley \& Sons, New York, 438 p.

Matteson, A. \& Herron, M. M. 1993: Quantitative mineral analysis by Fourier transform infrared spectroscopy. — SCA Conference Paper 9308, 1-16.

Mirabella, F. M. 2002: Principles, Theory, and Practice Of Internal Reflection Spectroscopy. — In: MiRABELla, F. M. (ed.): Internal Reflection Spectroscopy: Theory and Applications. — Marcel Dekker, New York, 17-52.

Müller, C. M., Pejcic, B., Esteban, L., Piane, C. D., Raven, M. \& Mizaikoff, B. 2014: Infrared attenuated total reflectance spectroscopy: an innovative strategy for analyzing mineral components in energy relevant systems. - Scientific Reports $\mathbf{4}$, 6764. https://doi.org/10.1038/srep06764 
NAEs, T., IsAKsSOn, T., FEARn, T. \& DAVIES, T. 2002: A user-friendly guide to multivariate calibration and classification. — NIR publications, Chichester, $344 \mathrm{p}$.

PAlayangoda, S. S. \& NGUYEN, Q. P. 2012: An ATR FTIR procedure for quantitative analysis of mineral constituents and kerogen in oil shale. - Oil Shale 29, 344-356. https://doi.org/10.3176/oil.2012.4.05

PlaninseK, O., Planinsek, D., Zega, A., Breznik, M. \& SRČIČ, S. 2006: Surface analysis of powder binary mixtures with ATR FTIR spectroscopy. — International Journal of Pharmaceutics 319, 13-19. https://doi.org/10.1016/j.ijpharm.2006.03.048

Reig, F. B., Adelantado, J. V. G. \& Moya Moreno, M. C. M. 2002: FTIR quantitative analysis of calcium carbonate (calcite) and silica (quartz) mixtures using the constant ratio method. Application to geological samples. — Talanta 58, 811-821. https://doi.org/ 10.1016/s0039-9140(02)00372-7

Ritz, M., VACulíKovÁ, L. \& PlevovÁ, E. 2011: Application of infrared spectroscopy and chemometric methods for the identification of selected minerals. - Acta Geodynamica et Geomaterialia 8, 47-58.

SAJó, I. 1994: Powder diffraction phase analytical system 1.7. — Users guide, Aluterv-FKI Kft., Budapest, 1-81.

SAVITZKY, A. \& GolaY, M. J. E. 1964: Smoothing and differentiation of data by simplified least squares procedures. - Analytical Chemistry 36, 1627-39. https://doi.org/10.1021/ac60214a047

Udvardi, B., Kovács, I. J., Fancsik, T., Kónya, P., Báthori, M., Stercel, F., Falus, Gy. \& Szalai, Z. 2016: Effects of Particle Size on the Attenuated Total Reflection Spectrum of Minerals. — Applied Spectroscopy 61, 283-292. https://doi.org/10.1177/ 0003702816670914

Washburn, K. E. \& BIRDWELl, J. E. 2013: Multivariate analysis of ATR FTIR spectra for assessment of oil shale organic geochemical properties. — Organic Geochemistry 63, 1-7. https://doi.org/10.1016/j.orggeochem.2013.07.007

Wentzell, P. D. \& Montono, L. V. 2003: Comparison of principal components regression and partial least squares regression through generic simulations of complex mixtures. — Chemometrics and Intelligent Laboratory Systems 65, 257-279. https://doi.org/10.1016/ s0169-7439(02)00138-7

Wold, S., Sjostrom, M. \& ERIKsson, L. 2001: PLS-regression: a basic tool of chemometrics. - Chemometrics and Intelligent Laboratory Systems 58, 109-130. https://doi.org/10.1016/s0169-7439(01)00155-1

Woods, B., Lennard, C., Kirkbridge, K. P. \& Robertson, J. 2014: Soil examination for a forensic trace evidence laboratory — Part 1: Spectroscopic techniques. — Forensic Science International 245, 187-194. https://doi.org/10.1016/j.forsciint.2014.08.009

Kézirat beérkezett: 2017. 06. 16. 
